\title{
6. Thinking and Working Politically? The Role of External Actors in Decentralization Reforms in Morocco and Tunisia
}

\author{
Sylvia I. Bergh
}

\section{Introduction $^{1}$}

This chapter builds on recent works on decentralization in the MENA region and extends the analysis to the role of external aid donors in decentralization reforms in Morocco and Tunisia (see Demmelhuber et al. 2020; Vollmann et al. 2020; Vollmann 2020). To do so, I build on the definitions and detailed accounts of the nature of neopatrimonialism in the MENA region, in order to focus on the donors' own diagnoses of the problems that their programs aim to solve. I furthermore aim to assess the extent to which donors are "politically aware" of the design and implementation of their programs, as well as their potential to disrupt entrenched political and administrative interests, and open up spaces for bottom-up civic engagement and scrutiny. ${ }^{2}$

By focusing on only two donors in two countries with five program/ project case studies, the chapter illustrates Berthin's $(2018,6)$ argument that aid support does not operate in a linear continuum, but is rather dependent on several contextual variables and incentives. In other words, the form aid takes on and the mode it is delivered through matters greatly.

1 I would like to thank all the interviewees for their time and useful feedback on an earlier version of this chapter, and Natalie Margossian for her excellent research assistance. I am also very grateful to Erik Vollmann and Thomas Demmelhuber for their continued encouragements to complete this chapter, as well as their and Roland Sturm's very constructive comments on an earlier version of this chapter. Finally, I wish to acknowledge the support from colleagues at the Center of Expertise on Global Governance at The Hague University of Applied Sciences.

2 In general, this area of research does not seem to have been much explored empirically in the decentralization literature. See Bunk (2018) for an exception and excellent example on the role of donors in the decentralization process in Mozambique. Dickovick (2013) provides a comprehensive theoretical account of foreign aid and decentralization. The most recent evaluation of World Bank support to decentralization is World Bank (2008). 
This is particularly relevant regarding the support for decentralized governance, which is a highly sensitive political issue. As Aliriza $(2018,39)$ observes for Tunisia's decentralization reform, "the degree to which power is devolved in the framework of decentralization is a matter of politics, contestation, and negotiation rather than any top-down, technocratic, discrete policy roadmap". Indeed - as Sturm and Demmelhuber put forward in this volume - the existence of (informal) neopatrimonial networks as well as of patronage-based relations of dependence and their interplay with formal politics, entails that normative goals of decentralization are rarely, if ever, achieved. This chapter builds on the assumption common to the other chapters of this volume: Fiscal decentralization is used as a strategic tool by central-level neopatrimonial networks to provide incentives that ensure the loyalty of regional and local elites, which leads to an entanglement of central, regional, and local elite networks.

Since the 1980s, decentralization reforms have been part of neoliberal public sector reforms promoted by the World Bank and the IMF. However, these reforms mostly comprised the delegation of tasks and powers to subnational branches of central state ministries or other appointed officials (a process known as administrative decentralization or deconcentration), rather than to elected subnational governments. Only the latter constitutes political decentralization (Bergh 2012a; Harb and Atallah 2015; Vollmann 2020).

Clearly, the Arab uprisings originated in socio-economic grievances, which resulted from long-standing regional disparities within many MENA countries. Both the MENA regimes that survived the uprisings and those that newly emerged after the protests subsided saw decentralization reforms as a possibility to address these grievances and to establish or increase their legitimacy in the eyes of the citizens. In addition, Western donors, including the IMF and the World Bank, were left discouraged from previous attempts at democracy promotion that had deteriorated into civil war (e.g. Syria) or failed statehood (e.g. Libya, Yemen), and believed decentralization reforms to be a less invasive possibility for reform (Vollmann 2020, 16; Demmelhuber et al. 2020, 504).

As a result, following the new constitution in 2011, major decentralization laws were passed in Morocco in 2015. Regional and local elections took place the same year. In Tunisia, a new constitution was adopted in 2014. Extensive decentralization laws were passed and local elections were held in 2018. In both countries, these processes were and still are supported by several multilateral and bilateral donors, such as the World Bank, UNDP, the Deutsche Gesellschaft für Internationale Zusammenarbeit (the German Agency for International Cooperation - GIZ), and USAID. 
However, there is rising concern that such donor cooperation might help stabilize authoritarian regimes, as has occurred in the area of international democracy promotion (Van Hüllen 2019, 883). Indeed, research has shown that external donors focus mainly on technical issues and ignore the political instrumentalization of formal structures of decentralization by domestic elites. They thereby may unwittingly contribute to fostering clientelism (Bunk 2018, 328, 331). ${ }^{3}$ As Van Hüllen observes, studies of authoritarian regime stability and change already flourished before the Arab uprisings. While they provide important insights into the internal dynamics of authoritarianism, they rarely include the interaction with external actors (Van Hüllen 2019, 871). ${ }^{4}$ This chapter thus aims to contribute to filling the knowledge gap around the international dimension of center-periphery relations in (semi-)authoritarian states.

If we accept the premise that decentralization processes are inherently political and that donor support may (unwittingly) contribute to authoritarian survival by extending neopatrimonial clientelist networks, then it is relevant to know to what extent donors are aware of and are able to navigate these dynamics. We ask to what extent they are Thinking and Working Politically (TWP). TWP refers to "politically informed programming", i.e. the design of development interventions that reflect and respond to the wider political context and are embedded in local and regional realities (Dasandi et al. 2016, 1).5 In particular, we want to know whether donor programs are based on some form of political economy of decentralization (PED) analysis ${ }^{6}$. In its Independent Evaluation Group review of decentralization interventions, the World Bank (2008) emphasized the need to es-

3 Bunk $(2018,328)$ goes on to say that "domestic elites in turn perceive external donors as acting informal, in the sense of side-lining formal democratic structures, such as the parliament. This perceived legitimation deficit of donors may contribute consciously or unconsciously to resistance to externally introduced democratization by domestic elites." While the aspect of donors' legitimation deficit is very relevant, it lies outside the scope of this article.

4 Van Hüllen (2019, 871) here refers to Bellin (2012); Burnell and Schlumberger (2010); Schlumberger (2007); Volpi (2017); and von Soest (2015).

5 As Dasandi et al. $(2016,1)$ note, there has been considerable interest in and debate on "thinking and working politically" (TWP) over the past decade, principally with reference to the programs supported by foreign aid donors (Andrews 2015; Booth and Unsworth 2014; Carothers and de Gramont 2013; Denney and Domingo 2017; Hout 2012; Hudson and Leftwich 2014; Rocha Menocal 2014; Whaites et al. 2015; Yanguas and Hulme 2015).

6 According to Eaton et al. (2011, 5), "political economy analysis is concerned with the interaction of political and economic processes in a society: the distribution of power and wealth among different groups and individuals, and the processes that 
tablish clear political ownership prior to engagement. This goes beyond "ticking the box" of having adopted a national decentralization policy or strategy and appreciates that ownership and "political will" are considerably more complex (Eaton et al. 2011, 61-62). ${ }^{7}$

According to Fritz and Levy (2014, 3), in the late 2000s, Political Economy Analysis (PEA) by the World Bank (as part of the Bank's Governance and Anticorruption strategy and financially supported by several European donor agencies) developed from being an unusual measure commissioned by a forward-thinking team within the organization, to becoming a routine discussion point for proposed operations. Interestingly, a review of eight carefully selected case studies revealed that despite the diversity of both country settings and problems under consideration, the role of clientelism and the significance of incentives on managing political support was a common theme for all of them (ibid., 8).

I thus derive three research questions which I will be explore in this chapter. Firstly, to what extent were the main features of the political economy of decentralization (including fiscal aspects and neopatrimonial networks) taken into account when the programs were designed? Secondly, to what extent was the staff implementing the programs aware of these political economy aspects, and to what extent did the implementation of their programs challenge or consolidate neopatrimonial networks? Thirdly, to what extent are donor interventions coordinated in order to minimize the risk of fragmentation and duplication, as well as of national stakeholders cleverly "playing off" the various donors against each other in order to maximize the financial benefits without committing to fundamentally challenging the elite's vested interests? In line with other chapters in this volume, I adopt a broad conceptualization of neopatrimonialism that includes phenomena commonly observed in (semi)authoritarian and transition regimes, such as clientelism, corruption, co-optation of local elites,

create, sustain, and transform these relationships over time”. When it comes to PED analysis, at least four major issues should be considered: first, the initial context and motivations for decentralization reform; second, the key actors involved in decentralization-politicians, bureaucrats, and citizens-and the incentives that condition their behavior with respect to reform design and implementation; third, the current stage of reform and its trajectory as it has unfolded since the initial decision to decentralize; and fourth, the role and incentives of key external development partners with respect to decentralization, both individually and collectively (Eaton et al. 2011, 7-8).

7 As Dickovick $(2013,10)$ points out, central government actors' "choice" to decentralize reflects an incentive to decentralize, not so-called "political will" (for an excellent critical conceptual discussion of political will, see Hudson et al. (2018)). 
elite capture of public goods, election fraud and vote-buying, and opening up controlled spaces for political competition (to facilitate elite rotation, balancing power relations, etc.).

The remainder of this chapter is structured as follows: The next two sections discuss the case study selection, the research methods and limitations, respectively. Short backgrounds to the decentralization reforms in Morocco and Tunisia, as well as brief introductions of the case study programs and projects will follow. The core of the chapter is structured around the presentation and discussion of the findings related to each of the three research questions. The final section concludes this contribution.

\section{Case study selection}

The case studies were selected based on an initial inventory of donor programs to support decentralization in various countries of the MENA region that hosted projects by the World Bank, the GIZ, and the UNDP. ${ }^{8}$ I limited the analysis to World Bank and GIZ programs and projects in Morocco and Tunisia, given that these external actors' involvements are substantial and comparable in terms of their structure and orientation regarding multilateral versus bilateral, loans versus grants, and investment loans versus technical assistance aid modalities. Morocco and Tunisia are also the most advanced countries in the region when it comes to decentralization reforms, yet they exhibit different post-Arab spring trajectories. Table 1 presents an overview of the five case studies discussed in this chapter. ${ }^{9} \mathrm{Un}-$ fortunately, the GIZ's project "Support for decentralization in Tunisia"10 could not be included, as interviews did not take place in time.

8 The GIZ is strictly speaking not a donor but an implementing agency for technical cooperation. When it comes to German development cooperation, it is more correct to refer to the German Federal Ministry for Economic Cooperation and Development (known as BMZ) as the donor (Pers. Comm. Interviewee 3 on 31 March 2021). Hence, I sometimes use the term "external actor" rather than "donor" in this chapter when referring to the GIZ.

9 Note that the Casablanca Municipal Support PforR loan is discussed as part of the Municipal Performance program. The additional financing loan for the Urban Development and Local Government Program for Tunisia is not treated as a separate program.

10 See GIZ (2021d). This project provides legal advice on how to implement the constitution in terms of decentralization, and advice to sectoral ministries on how to decentralize their services to local and regional levels (Interviewee 2). Between 
Table 1: Overview of program/project case studies ${ }^{11}$

\begin{tabular}{|c|c|c|c|c|}
\hline Donor & Name of the program & $\begin{array}{l}\text { Period of } \\
\text { implementation }\end{array}$ & Amount & $\begin{array}{l}\text { Geographic } \\
\text { focus area }\end{array}$ \\
\hline \multicolumn{5}{|c|}{ Morocco } \\
\hline $\begin{array}{l}\text { World } \\
\text { Bank }\end{array}$ & $\begin{array}{l}\text { Municipal Performance } \\
\text { Program-for-Results } \\
\text { Project for Morocco }\end{array}$ & $2019-2024$ & $\begin{array}{l}300 \text { million USD } \\
\text { (total cost: } 760 \\
\text { million USD) }\end{array}$ & $\begin{array}{l}\text { Most regions (see } \\
\text { footnote } 25 \text { for a } \\
\text { list) }\end{array}$ \\
\hline $\begin{array}{l}\text { World } \\
\text { Bank }\end{array}$ & $\begin{array}{l}\text { Casablanca Municipal Sup- } \\
\text { port Program-for-Results } \\
\text { Project for Morocco }\end{array}$ & $2017-2022$ & $\begin{array}{l}200 \text { million USD } \\
\text { (total cost: } 550 \\
\text { million USD) }\end{array}$ & Casablanca \\
\hline GIZ & $\begin{array}{l}\text { Supporting the regional- } \\
\text { ization process in Morocco }\end{array}$ & $2017-2021$ & 5.0 million Euros ${ }^{12}$ & $\begin{array}{l}\text { Four regions: } \\
\text { Casablanca-Settat, } \\
\text { Marrakesh-Safi, } \\
\text { Oriental and } \\
\text { Souss-Massa }\end{array}$ \\
\hline GIZ & $\begin{array}{l}\text { Strengthening citizen- } \\
\text { centered local government }\end{array}$ & $2015-2021$ & 5.33 million Euros & $\begin{array}{l}\text { Nine medium- } \\
\text { sized cities: Lar- } \\
\text { rache, Beni Mel- } \\
\text { lal, Tiznit, } \\
\text { Taroudant, } \\
\text { Meknès, Ouarza- } \\
\text { zate, Khemisset, } \\
\text { Ben Guérir, } \\
\text { Bensliman }{ }^{13}\end{array}$ \\
\hline
\end{tabular}

2012 -2016, the GIZ project "Decentralisation and support to subnational government" was also implemented, see evaluation report (GIZ 2017).

11 See the links to the projects in the order they are listed in the table below: https://projects.worldbank.org/en/projects-operations/project-detail/P168147 https://projects.worldbank.org/en/projects-operations/project-detail/P149995 https:/www.giz.de/en/worldwide/81969.html https:/www.giz.de/en/worldwide/38695.html https://projects.worldbank.org/en/projects-operations/project-detail/P130637 https://projects.worldbank.org/en/projects-operations/project-detail/P167043 https:/www.giz.de/en/worldwide/31897.html

12 Pers. Comm. Interviewee 3 on 31 March 2021.

13 Pers. Comm. Interviewee 4 on 31 March 2021. 


\begin{tabular}{|c|c|c|c|c|}
\hline Donor & Name of the program & $\begin{array}{l}\text { Period of } \\
\text { implementation }\end{array}$ & Amount & $\begin{array}{l}\text { Geographic } \\
\text { focus area }\end{array}$ \\
\hline \multicolumn{5}{|l|}{ Tunisia } \\
\hline $\begin{array}{l}\text { World } \\
\text { Bank }\end{array}$ & $\begin{array}{l}\text { Urban Development and } \\
\text { Local Government Pro- } \\
\text { gram for Tunisia }\end{array}$ & $2014-2023$ & $\begin{array}{l}300 \text { million USD } \\
\text { (total cost: } 363 \\
\text { million USD) }\end{array}$ & $\begin{array}{l}\text { All } \\
\text { municipalities }\end{array}$ \\
\hline $\begin{array}{l}\text { World } \\
\text { Bank }\end{array}$ & $\begin{array}{l}\text { Urban Development and } \\
\text { Local Governance Pro- } \\
\text { gram Project for Tunisia - } \\
\text { Additional Financing }\end{array}$ & $2018-2023$ & 130 million USD & $\begin{array}{l}\text { All } \\
\text { municipalities }\end{array}$ \\
\hline GIZ & $\begin{array}{l}\text { Initiative for municipal } \\
\text { development in Tunisia }\end{array}$ & $2015-2023$ & $\begin{array}{l}10.64 \text { million } \\
\text { Euros }\end{array}$ & 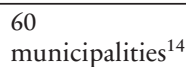 \\
\hline
\end{tabular}

Own depiction.

The two World Bank case studies were chosen in particular due to their considerable size in terms of loan amounts. They moreover directly aim to significantly change resource allocations to local governments and reduce financial oversight by the center, which are key elements of potentially disrupting patrimonial elite networks (see Demmelhuber et al. 2020). They also represent examples of the new World Bank Program-for-Results (PforR) instrument launched in 2012, which is rapidly becoming a significant financing mechanism. ${ }^{15}$

Under PforR, disbursements are conditional on "results". The instrument intends to improve the effectiveness of service delivery programs and

14 This number includes the municipalities in which the main project activities took place, but does not include the number of municipalities in which single activities were implemented, such as support for website creation and support by supplying sanitary equipment during the COVID-19 pandemic. For an interactive map, see UMap (2021).

15 Runde (2015) argues convincingly that the rise of the PforR instrument is due to the changed global donor landscape (including the rise of China) and the need for the World Bank to reassert its relevance given that an increasing number of developing countries now enjoy access to global capital markets. The PforR instrument means that the World Bank can hold a position in development cooperation as one partner among many. For instance, rather than building $5 \mathrm{~km}$ of new roads that strictly adhere to long-standing labor and procurement guidelines, while having no influence on the $495 \mathrm{~km}$ of roads built by other actors, such as China, the World Bank can offer its expertise and insist on some adherence to its standards for the construction of $500 \mathrm{~km}$ of roads. It can thus overall make a much larger impact. The largest PforR portfolios by project count are in Ethiopia, Tanzania, Morocco, India and Pakistan (see World Bank 2019b, 4, see also graph on p. 25). The PforR in the amount of US\$300 million to support Morocco's National Initiative for Human Development 2 (2012-2016) received satisfactory ratings on all major criteria (ibid., 12). 
to bridge a perceived instrument gap between investment loans (IL) best suited to large capital projects, and quick-disbursing policy loans (DPLs) designed to encourage policy reforms. While ILs must comply with a standard set of social and environmental as well as fiduciary safeguard policies, PforR operations assess country safeguard systems and, where necessary, seek to strengthen them rather than to segregate Bank funds into a special pool administered through Bank processes. In this way, the project (loan) can be leveraged to build wider institutional capacity and improve the effectiveness of the entire program, which is typically co-funded by the government and other donors. Early indications are that PforRs have indeed increased attention to the importance of results frameworks and encouraged partnerships and client government ownership through the focus on shared goals (Gelb and Hashmi 2014, 1, 3-4). ${ }^{16}$ As Runde (2015) explains, linking funding to results gives political capital to reform-minded technocrats and encourages institutional entrepreneurs to form coalitions with more senior leaders, who would otherwise favor preservation of the status quo. For this type of loan, it is thus even more important for World Bank staff to be TWP, especially in (semi)authoritarian and transition contexts, such as Morocco and Tunisia.

I have chosen the German agency for international cooperation (GIZ) as the second external actor to be analyzed in this chapter, given its significant (mainly technical assistance) support to decentralization reforms in the two countries. GIZ conceives itself as a professional and apolitical agency that implements German or multilaterally financed projects (Holthaus 2019, 1220; this was confirmed by Interviewee 2). The fact that it only administers grants rather than loans also make it an interesting case for comparison with the World Bank programs. Possibly, these two different aid modalities open up different types of opportunities for TWP. ${ }^{17}$

16 There is no room here to discuss the PforR instrument in more detail, but relevant questions arise around program credibility in face of pressure to disburse, the independence of monitors hired by the country or by the Bank, and the desirability of publishing results linked to the Disbursement Linked Indicators (DLIs), which would allow civil society to monitor the veracity of assessments (see Gelb and Hashmi 2014, 7, 16-19; see also Runde 2015). For an Early-Stage Assessment of the PforR instrument by the World Bank's Independent Evaluation Group (IEG), see IEG (2016).

17 Although it is tempting to compare the World Bank and GIZ in terms of their leverage vis-à-vis the recipient government, especially when it comes to political economy-related conditionality, such a comparison would not be appropriate. Rather than only looking at the GIZ, one would have to compare the World Bank with the overall portfolio of German development cooperation in the de- 


\section{Research methods and limitations}

This chapter relies on a critical reading of the Project Appraisal Documents for the two World Bank loans (as well as related documents including implementation progress reports), and of a limited number of documents received from GIZ as well as online interviews with five donor officials conducted during September-December 2020. ${ }^{18}$ All interviews lasted approximately one hour, except for one 30 minutes long interview. In line with the research questions, the interviews aimed at a) getting more information on the case study programs and projects, and their Theory of Change generally; b) assessing the extent to which the design and implementation of the programs and projects show an awareness of political economy considerations; and c) evaluating the extent to which there is coordination between donors. In order to enable them to give their candid views on the topic, the interviewees were promised anonymity and are hence only referred to as "Interviewee 1", "Interviewee 2" etc. in the text. They were also given the opportunity to review a pre-final version of this chapter. Apart from providing valuable additional information, the five interviewees in some instances requested paraphrasing or nuancing some of the direct quotations.

This study is limited in several ways. First, research on this topic is restricted by the fact that PEA is frequently treated as sensitive and confidential, including by national governments themselves. These are reluctant to open any critical analysis to the public domain, especially on sensitive topics, such as individuals' or groups' control over large swaths of economic activity, or politicians' use of public funds to repay their electoral campaign supporters. In turn, World Bank (and other donor) country teams face a strong incentive to maintain a good relationship with the respective governments in order to avoid programs being stalled (Fritz and Levy $2014,20)$. Second, representing the views of only a few donor officials, this chapter omits the important local perspectives of these reforms and the

centralization sector for both countries. For Tunisia, the latter consists of several decentralization projects as well as grants and loans provided by the German Development Bank (known as KfW). It is a portfolio of several 100 million Euros under auspicies of the BMZ (Pers. Comm. Interviewee 2 on 31 March 2021). See also the section on "The GIZ projects in Tunisia" for more details.

18 Hence, the interviews in Morocco did not discuss the recent diplomatic tensions between Morocco and Germany. For details, see for example Bachir (2021). 
donors' roles in them. ${ }^{19}$ This chapter moreover does not engage in the discussion on possible ideological drivers of decentralization reforms promoted by the World Bank. ${ }^{20}$ However, despite these limitations, this chapter can offer a new and empirical perspective on donor involvement in decentralization reforms in North Africa, thereby adding to the insights presented in the other chapters of this volume.

\section{A brief background to decentralization in Morocco ${ }^{21}$}

Morocco has three levels of local government: regions, provinces (in rural areas) and prefectures (in urban areas), and urban and rural municipalities (communes in French). All local authorities are subject to the supervision (tutelle) of an officer of the Ministry of the Interior who represents state authority and ultimately reports to the King. Municipalities were first established in 1960. They did not have extensive powers or resources until 2002, when the Third Municipal Charter - and its amended version that became effective in 2009 - expanded their responsibilities, clarified their role in reducing poverty and exclusion, and included the possibility of entering into partnerships with local associations. The regime (known as the makhzen, i.e. the palace and its clients) responded almost immediately to the 2011 protests by announcing a draft constitution. Its first article states that "the territorial organization of the Kingdom is decentralized" and introduces the principle of "advanced regionalization" to make regions, in addition to municipalities, key levels of local government. ${ }^{22}$ However, it took until 2015 for three Organic Laws (OLs) to be issued, which specified and operationalized the spirit of the 2011 Constitution at the municipal, regional, and provincial/prefectural levels. The region has no authority over the provinces/prefectures and municipalities - the three separate OLs are (deliberately?) ambiguous. This allows the King to arbitrate between various

19 For in-depth accounts of the local perceptions and cultural framings of the decentralization reform in Tunisia, see Salman (2017) and Yousfi (2019).

20 See Salman (2017) for the argument that the World Bank is pushing decentralization reforms as they ultimately enable municipalities to become creditworthy, which means that they could engage in public-private partnerships with the private sector and eventually take on loans from the World Bank to finance their investments without sovereign guarantees.

21 This section is mainly based on Bergh (2020), see also Bergh (2017) and chapter 4 (this volume) for a much more detailed description.

22 For an analysis of the advanced regionalization process, see Bergh (2021). 
power centers and interests, significantly reducing the accountability between levels and towards the citizens.

Compared to the 2009 Municipal Charter, the powers of the municipal council have barely been modified by the 2015 law. However, there now exists the possibility for citizens and local associations to submit petitions to the municipalities, and provisions to increase the transparency of municipal affairs. ${ }^{23}$

There are three main challenges to the decentralization process in Morocco: legal ambiguities, financial resources, and human resources. The lack of a clear framework and implementation provisions mean that the 2015 OL on municipalities still largely exists only on paper. Moreover, the tutelle has not fully disappeared. Municipalities are very dependent on central government transfers financially, and municipal budgets are still far from being able to cover the increasing needs of municipal infrastructure, equipment, and services (see also chapter 5). Local councilors are largely untrained. This allows the King to present himself as the only institution capable to respond to citizens' needs and expectations. ${ }^{24}$

Indeed, programs such as the National Initiative for Human Development (known under its French acronym INDH) that bypass local governments and give more power to the Ministry of the Interior are another example of the monarchy's use of (purposefully incomplete) decentralization reforms that work to the regime's advantage (Bergh 2012b). As Bohn and Vollmann (chapter 4) describe in detail, neopatrimonial networks are well anchored within the makbzen, top representatives of the Ministry of the Interior and other government ministries, business elites, political party elites, and the relationships between them. Decentralization reforms are used to disperse power and responsibilities between elites, to enlarge networks profiting from state funding, and to hinder effective coordination among them in order to neutralize their potential threat to regime stability.

23 It remains to be seen how the new law governing information access is used at the local level to enforce these transparency provisions. See Shalaby and Bergh (2020).

24 Similarly, Vollmann et al. $(2020,22)$ argue that "institutional failure of elected institutions is used to highlight the virtues of the palace's supposed technocratic approach. An example of this is the widespread rejection of the first wave of flawed regional development plans, political infighting in city councils or the suspension of the regional council of Guelmim-Oued Noun by the Minister of Interior in May 2018." 


\section{The World Bank's Municipal Performance Program-for-Results program in Morocco}

The Municipal Performance Program-for-Results targets around $100 \mathrm{mu}-$ nicipalities in almost all regions in Morocco, ${ }^{25}$ including all municipalities with a population of more than 50,000 inhabitants, and municipalities that are a provincial administrative centers (chef lieu; World Bank 2019a, 23). ${ }^{26}$ It has an overall operating cost of 760 million USD, of which the Moroccan government contributes 346 million, the World Bank 300 million, and the French Agency for Development 114 million (World Bank 2019a, 7-8).

The rationale of the program - as described in the World Bank's Program Appraisal Document (PAD) - is based on Morocco's sustained urbanization trend. This trend entails the increase of poverty pockets in cities and high unemployment rates, as well as huge needs for infrastructural investment (exacerbated by climate-induced shocks, such as floods, landslides, droughts, wild fires, and heat waves; World Bank 2019a, 13, 15, 31). The PAD (World Bank 2019a, 13) further notes that the implementation of decentralization reforms remains a priority, as the country's population continues to display low levels of trust in administration and high levels of dissatisfaction with the quality of public services. Indeed, it argues that "the Government's decentralization agenda stems from the recognition of the pivotal role of municipalities in renewing the social contract in Morocco" (World Bank 2019a, 14). The PAD also points out that the 2011 Constitution in its article 136, "establishes the principle of administrative freedom of municipalities, thus acknowledging the end of the administrative control or tutelle of the Central Government over municipalities" and instead moves toward support or accompagnement. This qualitative change "provides the opportunity to move [from compliance] towards a performance-based approach to supporting municipalities, but also calls for an

25 The Program area includes the regions of Béni Mellal-Khénifra, Casablanca-Settat, Drâa-Tafilalet, Fès-Meknès, Marrakech-Safi, Oriental, Rabat-Salé-Kénitra, SoussMassa and Tanger-Tétouan-Al Hoceïma; the provinces of Guelmin, Tan-Tan and Sidi Ifni; and the municipality of Assa (World Bank 2019a, 23).

26 The combined population of the targeted municipalities represents more than $80 \%$ of Morocco's urban population and nearly $50 \%$ of its total population. These are municipalities where improvements in institutional and service delivery performance are expected to have the largest impact and where most of Morocco's demographic growth and thus the highest urban infrastructure investment needs will be concentrated in the future years (World Bank 2019a, 20). 
ambitious capacity building program to address municipalities' existing capacity constraints" (World Bank 2019a, 14, 17).

Indeed, the PforR loan is meant to strengthen the mechanisms for allocating and transferring large parts of the $30 \%$ Value Added Tax (Taxe sur la Valeur Ajoutée, TVA). The TVA is transferred to municipalities after incentivizing municipalities to (a) increase their institutional capacity; (b) improve their performance in the delivery of municipal services; and (c) ensure their financial sustainability and capacity to finance the required investments (World Bank 2019a, 17). As Interviewee 1 explained:

The idea is that by the end of the program [i.e. at the end of 2024] there would be 5.5 billion Dirham ${ }^{27}$ transferred in performance-based grants from the government to the municipalities. And out of this, 4 billion would come from the donors, and 1.5 would come from the Compte d'affectation special (CAS) TVA. [...] That [amount] does not come from the unconditional transfers. So they are not reducing unconditional transfers to finance this.

In other words, the performance score does not affect the unconditional transfers that municipalities rely upon to finance their recurrent expenditure, such as salaries.

The Municipal Performance Program has its origins in the Casablanca Municipal Support Program, which the World Bank had financed earlier with the same loan type (PforR), and which was widely regarded as very successful. Hence, the new Municipal Performance Program would be able to learn from and build on the Casablanca experience, for example nationally rolling out the digitalization of administrative procedures for the issuance of building permits and commercial licenses, a digital revenue management system, and the digitalization of municipal civil registrars (World Bank 2019a, 17). According to Interviewee 1, personal relationships also mattered, as the wali $^{28}$ of Casablanca became the wali at the DG$\mathrm{CL}^{29}$ around the time that the World Bank was preparing the project in Casablanca. At first, the idea was to repeat the Casablanca project in other cities, but the discussions lead to the design of the national level program supporting municipal performance across Morocco instead.

271 USD is worth approx. 9 Dirham.

28 The wali is the governor, appointed by the King and part of the Ministry of the Interior's hierarchy.

29 The governor or head of the Directorate General of Local Governments (Direction Générale des Collectivités Locales - DGCL) in the Ministry of the Interior is amongst others responsible for the implementation of decentralization reforms. 
The bank's justification for using a PforR loan rather than a DPL lies in the PforR instrument's successful record of accomplishment (including in Morocco). An additional factor is that "the PforR instrument appears well fitted [...] as it allows to support an ambitious Government program of reforms based on performance improvement and the achievement of concrete results, while financing a large number of investment subprojects developed and implemented by a broad range of municipalities" (World Bank 2019a, 19). As Interviewee 1 explained:

We finance a program, we don't finance specific expenditure, and so for municipal development projects it's much better because when you finance municipal expenditure potentially you finance hundreds or thousands of contracts, so if I need to do this procurement no-objection [procedure] on every small contract $[. .$.$] it's not going work. With$ the PforR it's possible to do this at the program level so you assess the systems for fiduciary management, for environmental and social management ${ }^{30}$ [etc.], you try to identify gaps at the system level and what you monitor is how well the systems work instead of giving a no-objection on each and every transaction. That allows you to define a one billion dollar program and to say, 'I'm going to finance 200 million out of this 1 billion', and you are not going to determine which contracts, which transactions fall under my 200 million; I'm looking at the program, and as long as the program works with systems that I find adequate, I can disburse based on results.

The program is structured around three main subprograms, of which subprogram 1 on "developing and implementing a performance-based grants transfer system on Participating Municipalities" is the most relevant for this chapter, as it potentially affects pre-existing patronage networks (World Bank 2019a, 20). ${ }^{31}$ As explained in the PAD (World Bank 2019a, 21), the subprogram

30 The appraisal for a PforR loan is informed by a technical assessment with a focus on strategic relevance and technical soundness of the program and its expenditure framework, a fiduciary assessment with a focus on the procurement and financial management arrangements, and an environmental and social systems assessment with a focus on the potential environmental and social impacts and risks (see IEG 2016, ix; see also the World Bank's 2017 Program-for-Results policy [World Bank 2017] - here, neither the terms "political" nor "political economy assessment" are mentioned; the same is true for the World Bank PforR directive 2020 (World Bank 2020c)).

31 The other subprograms are Subprogram 2: strengthening the institutional framework for inter-municipal cooperation; and Subprogram 3: enhancing the organi- 
will introduce an annual performance assessment of the Participating Municipalities, based on a performance framework consisting of Minimum Mandatory Conditions (MMCs) and Performance Indicators (PIs). The subprogram will incentivize municipalities to improve their performance through financial incentives consisting of performancebased investments grants. The performance grants will be allocated to municipalities based on an objective and transparent formula taking into account each municipality's population, its achievement of the MMCs, and its score on the different PIs. With support from the World Bank and the French Development Agency (AFD), the DGCL and the General Inspectorate of Territorial Administration (Inspection Générale de l'Administration Territoriale, IGAT) have developed a performance assessment framework consisting of a set of MMCs related to the existing legal provisions and of PIs articulated around complementary themes $[\ldots]$ targeted toward ensuring improvement of municipal performance and service to citizens.

Interviewee 1 explained the underlying idea as follows:

The idea is not to punish anyone, it's just to identify the capacity gaps, incentivize the municipality to close those gaps through peer pressure and financial incentives, and give them the tools to do so. That's a pretty simple model, you don't start from scratch, because you already have 10-12 existing projects for which you have a list of indicators. You don't have to go through a lot of, let's say, philosophical questions on what is performance, how do you measure it, [you can] look at different models, and those models tend to be quite similar because municipal management is not rocket science; the basics of managing municipal revenues, of managing municipal expenditures, reaching out to your citizens, they are pretty much the same whether you are in a rural panjayati raj in India or in Casablanca.

\section{Germany's interests in the MENA region and the GIZ projects in Morocco}

Before turning to the GIZ projects in Morocco, it is useful to give a brief background to Germany's involvement in the region. The country has maintained a prominent diplomatic, commercial and development pres-

zation and human capacities of Participating Municipalities (World Bank 2019a, 20). 
ence in the MENA for several decades, focused mostly on supporting political stability and promoting economic co-operation, with active engagement from German civil society groups and political party foundations. The 2011 Arab uprisings and their aftermath influenced Germany's domestic and international politics and resulted in the presence of several hundred thousand mostly Syrian refugees in Germany since late 2015. The growing importance of the MENA region for Germany is reflected in sharp increases in humanitarian and development aid to the region, which more than quadrupled from around EUR 750 million annually to around EUR 3.6 billion between 2011 and 2017. In 2015, Morocco overtook Egypt as the largest MENA recipient of German aid, and aid to Tunisia more than doubled from around EUR 87 million in 2009 to nearly EUR 188 million in 2016 (Furness 2020, 71, 75-76).

However, as Furness $(2020,71)$ points out, this remarkable increase has not been accompanied by a strategic policy statement that sets out the objectives of Germany's MENA aid program. The main regional policy paper of the German Federal Ministry for Economic Cooperation and Development (Bundesministerium für wirtschaftliche Zusammenarbeit und Entwicklung, BMZ) dates from 2008. It candidly pointed out the dangers of increasing poverty, societal instability, political repression and demographic change, and warns that security and migration problems are likely to emerge. It outlines three - partially unconnected - core areas for co-operation, in which Germany is an international leader: water, renewable energy, and vocational training (Furness 2020, 71, 75).

The 2008 MENA concept paper remained on the BMZ's website until mid-2018. There has been no follow-up publication for a regional aid policy framework in response to the post-Arab spring context. This is reflected in Germany's actual aid spending, which largely followed patterns established before the Arab uprisings. Additional spending has overwhelmingly concentrated on two areas, i.e. humanitarian aid in response to the Syrian civil war and loans for renewable energy generation in Morocco (which is expected to serve Germany's energy needs as well). However, an internal position paper published in August 2014 added "governance and education" as a co-operation sector, and promised to focus on four specific problems: youth unemployment; economic instability; the democratic deficit; and stability in crisis countries, especially with regard to the humanitarian crisis in Syria. To respond to these issues, the BMZ launched a EUR 400 million-budget line called "Special Initiative for Stability and Development in North Africa and the Middle East" (SI MENA) the same year (Fur- 
ness 2020, 71, 75-76). ${ }^{32}$ Indeed, given its name, it is not surprising that Furness concludes his study on Germany's post-Arab uprisings MENA aid program that "while there is little evidence of purposeful securitization of aid, stability has been privileged over support for unpredictable political change" (Furness 2020, 72, 75). ${ }^{33}$

All three GIZ projects studied in this chapter (see Table 1 above) originate from and are funded by the SI MENA. In Morocco, they coincided with the adoption of the organic laws on regions, provinces, and municipalities (2015), which further advanced the regionalization as well as decentralization processes. As Interviewee 4 explained, "it was really about jumping on the train and taking the train into the right direction here in Morocco regarding this whole opening towards more decentralization, regionalization, deconcentration and with this, democratization. There is this hope that this reform process launched in Morocco [...] after 2012 would also bring more democratic elements into everyday governance.”

The GIZ project entitled "Supporting the regionalization process in Morocco" (which officially started in 2017 but was effectively launched only in September 2018 and ended in January 2021), focused on supporting the advanced regionalization reform in four regions: Casablanca-Settat, Marrakesh-Safi, Oriental and Souss-Massa. It operated primarily by training representatives of the regional councils to represent the needs of their citizens, and educating employees from regional administrations on setting up a functioning administrative structure. The project also assisted the regions in establishing a system to monitor regional development plans and provided training for civil society organizations and advisory bodies on equal (gender) rights, the promotion of young people, and local economic development. ${ }^{34}$

32 Germany refused to reduce the capacities of its bilateral agencies in favor of multilaterally implemented projects after the 2005 Paris Declaration on Aid Effectiveness (Holthaus 2019, 1220). On the German website on this "Sonderinitiative zur Stabilisierung und Entwicklung in Nordafrika, Nahost", it is stated that 395,1 million Euros have been committed ("bereitgestellt") for 75 projects, to be implemented between October 2014 and December 2022 (see BMZ 2021a). For commitments by the German Development Bank (KfW) in Morocco, see KfW (2021a).

33 It is - of course - possible that the absence of clearly formulated strategic documents reflects a policy of "strategic ambiguity" for Germany to avoid being held responsible for non-fulfilled commitments later on (Furness 2020, 73).

34 See GIZ (2021c). There is no space here to present the advanced regionalization reform in detail, but see Bergh (2021) and Vollmann et al. (2020). 
The second project implemented by GIZ in Morocco, called "Strengthening citizen-centered local government" (which ran from October 2015 to January 2021; with a funding volume of 5.33 million Euros) focused on capacity building to make services more efficient, transparent and accessible, as well as on increasing citizen participation in municipal planning and political decision-making. In nine medium-sized cities (each with between 60,000 and 500,000 inhabitants; see table 1 for details), the project worked with political decision-makers and administrative staff to improve the administrative processes of the services and to set up citizens' advice bureaus. In these bureaus, citizens receive advice and information about available services and administrative processes. They are moreover referred to the relevant departments. ${ }^{35}$

\section{A brief background to decentralization in Tunisia ${ }^{36}$}

Since the country's independence, local governments in Tunisia have been under the scrutiny and control of the central government. They were significantly constrained in terms of resources and did not enjoy autonomous fiscal powers. The aftermath of the 2011 revolution saw a crisis in state authority at the local level: Local groups attacked municipal buildings and there was a widespread refusal to pay taxes. The issue of regional inequalities, which arguably triggered the revolution, continued to be a pressing issue. The new political elite, who was involved in the constitutional drafting process and composed of individuals with no role in the former regime, agreed on the decentralization of power as a guarantee against the return of authoritarian rule and as a structural response to unjust and imbalanced development policies. Chapter Seven of the constitution entitled "Local Authority", affirmed elected local and regional government as being autonomous institutions with financial and administrative autonomy and significant powers. Chapter Seven also abolished all a priori control by central government over local or regional authorities' decisions. These provisions were a radical departure from the highly centralized framework of decision-making in Tunisia and in much of the Arab world. In order to implement Chapter Seven, the Department of Local Authori-

35 See GIZ (2021a).

36 This section is mainly based on Kherigi (2020), see also chapter 4 (this volume) and Aliriza (2018), Baccouche (2016), Bel Haj Amor (2020), Salman (2017), Yerkes and Muasher (2018). 
ties of the Ministry of Interior, which in 2016 split off into the separate Ministry of Local Affairs (MLA), began drafting the new Local Authorities Code in March 2014. It was adopted in April 2018, just before the first election of municipal councils in May 2018.

The hyper-centralization of the Tunisian regime meant that prior to $2014,70 \%$ of the country was not municipalized and 86 of the now existing 350 municipalities were created after 2014. A majority still awaits the strengthening of their capacities (Vollmann and Bohn, chapter 5 in this volume, citing Tarchouna 2019). The municipal councils face huge challenges in governing effectively at the local level; mainly because the other ministries refuse to recognize the MLA's authority to lead and shape the reforms that directly affect their own powers and resources. This means that key aspects of decentralization remain unaddressed, such as reforming local taxation, local planning powers, the role of deconcentrated authorities, and mechanisms for coordination and cooperation. It also means that the developmental objectives of decentralization have largely been sidelined. Indeed, the new Code is incomplete, in conflict with a plethora of existing laws, and remains vague on administrative decentralization, which will be subject to a 27 -year process of negotiation with various ministries. Fiscal decentralization is equally weak ${ }^{37}$ and proposals to give municipalities new fiscal powers were resisted fiercely by the Ministry of Finance. However, municipal councils elected in 2018 have begun to lobby for greater powers and resources and are strengthening their national federation, which bodes well for the future.

In terms of neopatrimonial networks, Bohn and Vollmann (chapter 4 in this volume) note that even though Ben Ali was ousted in 2011, the economic elites in Grand Tunis and the Sahel and most cadres of the former regime's party (the Democratic Constitutional Rally, RCD) remained relatively unscathed. The latter competed massively in the 2018 local elections, while the former used the transition period to become active in political parties (also to gain immunity as MPs). This means that regional disparities continue (to the disadvantage of interior regions) and ministerial officials as well as local administrations mostly remain in place. Most importantly, old ties between tutelle agents, economic actors, and ministerial elites continue to be salient, which leads to intransparent decisions and financial allocations at the expense of new entrepreneurs from the interior regions (ibid.). It remains to be seen if donor-financed decentralization programs can break these ties.

37 See chapter 5 for details. 


\section{The World Bank's Urban Development and Local Governance Program in Tunisia}

The World Bank's Urban Development and Local Governance Program in Tunisia (launched in 2014), served as a model for the Moroccan program and in part involved the same World Bank staff members. The program is financed by a loan of 300 million USD, with the Tunisian government contributing an additional 63 million USD. It was supposed to end in 2019, but was extended until 2023, with an additional loan of 130 million USD (World Bank 2014, vi; World Bank 2020b; Interviewee 5). The PAD's country context diagnostic mentions regional disparities, high youth unemployment, and the need to ensure social peace and security as the main challenges for the Tunisian government. While the urbanization rate is very high, Tunisian municipalities only play a minor role in urban/local development. They suffer from low revenues and expenditure levels, widespread dissatisfaction with their service delivery, and exceptionally limited engagement of citizens, as well as a strong system of tutelle that constrains their decision-making and independence (World Bank 2014, 1-2, 6). The PAD notes, "Tunisian municipalities have not provided invited spaces', within which citizens are able to engage meaningfully with the 'local state' or to voice their preferences and priorities. Issues of accountability and participation have become more prominent, gaining importance in the wake of a post-revolutionary crisis of political legitimacy and a general deterioration in municipal services" (World Bank 2014, 3).

The PAD refers to the commitments to decentralization as noted in the 2014 Constitution, which includes "fully devolved and empowered LGs with autonomy for executing their mandates of providing local services according to transparent principles of participation by, and accountability to, their citizens". Similar to the dynamic in Morocco, the PAD further notes that "the changes mandated by the Constitution regarding local governance are transformational, as they effectively reverse the highly centralized previous structure, whereby central oversight and approval (tutelle) was exercised on all facets of Local Government accountability, decisionmaking, and capital works and service delivery-related investments" (World Bank 2014, 2).

At the time the program was designed, municipalities were regulated and monitored by the General Directorate of Local Governments (Direction Générale des Collectivités Publiques Locales - DGPCL), a key directorate within the Ministry of the Interior, which was transferred to the Ministry of Local Affairs (MLA) in 2016. In addition to its regulatory functions, the DGPCL is also responsible for managing the Local Government 
Common Fund (FCCL, Fonds Commun des Collectivités Locales), which provides municipalities with annual block grants to support their operating budgets. In addition, there is the Municipal Development Fund (CPSCL, Caisse des Prêts et de Soutien des Collectivités Locales), which reports to the MLA and includes the Ministry of Finance on its board. It provides municipalities with access to credit as well as to central Government funding to finance municipal investments (loans and capital grants; World Bank 2014, Interviewee 3 and Interviewee 5). The FCCL allocations to municipalities are purpose block grants entirely at the discretion of municipalities and were characterized as relatively transparent in the PAD (World Bank 2014, 3-4). However, the capital grants allocated by the central government were described as less predictable and transparent. At the municipal level, all investment needs were (and still are) systematized within Municipal Investment Plans (known as PICs). Financing for these PIC investments was mobilized from CPSCL loans to municipalities, central Government subsidies (managed on behalf of the center by CPSCL), and own-source municipal revenues. Central Government capital grants accounted for about a third of municipal investment expenditures. However, the problem was identified to be rooted in the fact that municipalities "face the increasingly serious issue of growing municipal debt, driven largely by the requirement that they borrow from the CPSCL to finance their capital investments" (World Bank 2014, 3, 5). Indeed, the PAD notes that half of all municipalities were unable to make debt payments and were technically in default. The fact that the final decision on investment selection cannot be taken by the municipalities, but is instead controlled by the central level, "fundamentally weakens the potential of municipalities to practice participatory governance and establish sound social contracts with their citizens" (World Bank 2014, 7). ${ }^{38}$

As in Morocco, the Program consists of three sub-programs, the first of which is again the most important one. It deals with municipal infrastructure delivery and receives the bulk of the loan (US\$ 591 million)..$^{39}$ It aims at reforming the problematic capital grants system by giving the municipalities the sole discretion over them (without any ex ante control by the central government). Key investment areas are road construction, rehabilitation and upgrading, street lighting, urban drainage/sewerage and other

38 For a more elaborate description of the municipal finance system at the time, see World Bank (2014, 15-18).

39 Subprogram 2 targets improving access to municipal infrastructure in disadvantaged neighborhoods. Subprogram 3 focuses on capacity support for improved LG institutional development and accountability (World Bank 2014, 11-12). 
environmental improvements, solid waste collection and street cleaning, parks and some recreation facilities, markets and slaughterhouses (World Bank 2014, 11-12).

The innovation lies in the fact that the capital block grants would be partly performance-based to incentivize the 264 Tunisian municipalities that existed in $2014 .{ }^{40}$ As in Morocco, the grant system would operate through two steps. The first is subject to the municipality meeting basic minimum mandatory conditions (MMCs), the second rewards municipalities according to their level of performance as determined by annual and independent performance assessments against predetermined criteria. These criteria include the implementation of participatory planning and transparency initiatives (World Bank 2014, 8, 15-16). ${ }^{41}$ The program further envisages the design and launch of a new e-Portal (Portail des Collectivités Locales). The portal would be a platform for sharing budget, procurement, and audit information for all LGs, as well as the results of LG performance assessments accessible to the public (and, progressively, the e-Portal would also host LG information on Participatory Planning and Participatory Budgeting processes; World Bank 2014, 17-18).42 Municipal borrowing from the CPSCL to implement the PICs would still be possible, but the CPSCL lending guidelines would be reformed in order to establish a stable balance between maximizing borrowings by the LGs and maintaining their financial viability (World Bank 2014, 12). Given that the Bank's own contribution was likely to provide about $82 \%$ of overall government program financing, it had (and arguably still has) great leverage to bring about significant changes, as contained in the Program Action Plan (PAP), Results Indicators (RIs) and Disbursement Linked Indicators (DLIs; World Bank 2014, 10). ${ }^{43}$

40 Interviewee 5 explained that the 86 new municipalities "are not submitted to the performance indicators. They are subject only to the minimal conditions because they are new - there wasn't an administration before, so it was decided that they will lighten up the process for them in the first years and then later on they will get up to speed with the rest of the municipalities".

41 See Bellamine (2015) for a scathing critique of the new allocation formula as it appeared to contradict Article 12 of the constitution mandating "positive discrimination" toward marginalized areas in development projects.

42 See Portail des collectivités locales [Local Collectivities Portal], Tunisian Ministry of Local Affairs and the Environment (2021).

43 See World Bank $(2014,21)$ for a list of DLIs. 
According to Interviewee 5, three performance assessments have been conducted:

We were really on track, we did two rounds of assessments before the elections, one after the elections $[\ldots]$ and despite the challenges of not having municipal councils [in 2014], we still went through in launching the system and the elected municipal councils arrived on a relative-

ly functioning system [in 2018]. Indeed, most municipalities were able to get satisfying scores in their annual performance assessment in 2019, but due to the COVID 19 crisis, the government decided to put on hold the 2020 annual performance assessment until further notice. ${ }^{44}$

\section{The GIZ projects in Tunisia}

In contrast to the ambiguous regional policy described earlier, Germany quickly pledged its support to post-revolution transformation in Tunisia (including in the Constitutional drafting process) and developed a clearly visible bilateral agenda. Germany portrayed itself as a legitimate partner, as the country is a (former) member of the community of transitional democracies and a state that managed regional unification (Holthaus 2019, 1225). Indeed, most GIZ-led projects in Tunisia are funded by the BMZ and focus on decentralization, communal development, and administrative reform (Holthaus 2019, 1223). ${ }^{45}$ This is because the German development cooperation, together with the World Bank and AFD, agreed with the Tunisian Government on a "Reform Matrix" for the governance sector, including a strong focus on decentralization. Accordingly, the GIZ projects are to a large extent part of the PforR program. ${ }^{46}$

44 See also World Bank (2020b, 12).

45 For commitments by the German Development Bank (KfW) in Tunisia, see KfW (2021b).

46 Pers. Comm. Interviewee 2 on 29 March 2021. This reform matrix is part of the "reform partnership" under the Marshall Plan with Africa. The partnership was concluded in 2017 and is a bilateral contribution to the G20 Compact with Africa initiative. It initially only provided support for reforms in the financial and banking sector, but since 2020 includes support for the modernization of public administration. In 2019, the BMZ newly committed a total of 294.8 million Euros, with 139.4 million Euros of that amount being allocated under the reform partnership (see BMZ 2021b). 
Interviewee 2 stated,

the strategic background of all the donor interventions $[\ldots]$ on this issue is the democratic change of the Arab revolution and the necessity to create legitimacy for the new democratic structures vis à vis the times of Ben Ali, because [there has to be] a 'democratic dividend' that the citizens really feel in an economic way but also in terms of relation to public authorities that the government and the situation in the region has changed.

Interestingly, Interviewee 2 also referred to the German federal model as a rationale to promote decentralization because of its expected benefits for the citizens.

As for the GIZ project in Tunisia studied here, it is called "Initiative for municipal development in Tunisia”. The project's duration is from 2015 to 2023 and has a funding volume of 10.64 million Euros. ${ }^{47}$ The project is quite similar to the municipal project in Morocco, as it focusses on training municipal employees and setting up citizens' offices. It also supports digitalization in partner municipalities in order to develop municipal services (e-services) and digital participation formats (e-participation). The discussion below focuses on the setting up of citizens' offices, which is the most relevant aspect for this chapter. Interviewee 2 explains that the idea of having one-stop-shops for municipal services is not an only German idea, as many countries employ this system. Interviewee 2 states, "For our projects we have been inspired by our strong experience working on that also in Armenia and Georgia with the governments there; we have created lots of citizen spaces and digitalized them. So this was inspired from our work there during the time we created this program in 2015. Maybe it's a German fingerprint but not a German solution.”

\section{Assessing the extent of TWP in the design stage}

This section presents and discusses the findings related to the first research question. It examines to what extent the main features of the political economy of decentralization (including fiscal aspects and neopatrimonial networks) were taken into account when designing the programs.

47 See GIZ (2021b); see also the project factsheet available at Loibl, Eckermann, and $\operatorname{Marx}(2020)$. 
According to the World Bank, the Moroccan municipalities' main problem lies in the "lack of incentives of Moroccan municipalities to strategically plan and effectively execute their investment budgets" (World Bank 2019a, 2). However, while the PAD notes that many municipalities had not yet voted on their five-year municipal action plans (Plans d'Action Communaux, PAC), it identifies the reasons for this "lack of incentives" solely in capacity constraints. This pertains to "weak capacities in terms of quality project management, including procurement, environmental and social management, a lack of sufficient qualified human resources (HR), a lack of modern technological equipment, and technical and administrative difficulties" (World Bank 2019a, 16). Indeed, potential political reasons are not mentioned, with the exception of a brief section in the PAD that notes, "the weak accountability relationship between municipalities and their citizens does not provide sufficient incentives for the municipalities to perform effectively" (World Bank 2019a, 16). However, rather than talking about local elections as a key issue in this relationship, the PAD points to the lack of municipal asset inventories and low levels of civic organization as the main issues, the latter of which are results of "historical limits on space for both information sharing and opportunities to engage" (World Bank 2019a, 16). World Bank staff nevertheless seem aware that there is a fine line between fostering the "right" and "wrong" type of Citizen Engagement (CE). As the PAD notes, political risks

stem from the introduction of innovative CE mechanisms: the opening of space for citizen participation can create high expectations that need to be properly managed and responded to, to avoid frustration and discontent. To mitigate this risk, the Program will build capacities at the municipal level to design, manage, and respond to citizens' demands for transparency, information, and participation (World Bank 2019a, 50).

In other words, the "supply" side of accountability must first be operational to then accommodate the requirements of the "demand" side.

In Tunisia, the World Bank Program was mainly designed to help the government reform the capital grant system. While the PAD does not mention political economy considerations explicitly, they are clearly part of the rationale:

The complexity of the inter-relationship between accessing grants, utilizing loans and providing counterpart funding, combined with the centralized system of determining eligibility for the grant funds is considered opaque and potentially inequitable. The system operates 
through procedures that are not perceived as transparent, objective and measurable, and are not predictable in a manner that facilitates consultation and effective planning (World Bank 2014, 6).

Apart from the political fluidity (notably the uncertainty of the timing of local government elections) as a risk for the program, the PAD observes that reforms such as the capital grant reforms "have proven to be difficult to implement and present a risk of capture by groups within the line ministries and the MoEF". Fostering government ownership is mentioned as the key strategy to mitigate (this) risk as "challenging activities and proposed reforms have been lengthily discussed with the counterparts during preparation and the Program builds upon a suite of ongoing and solid dialogue on decentralization and local governance reform [...]" (World Bank 2014, 36).

The passages cited here reflect the findings observed by the IEG's early assessment of PforR operations, which conclude that political economy constraints are behind many of the issues addressed by DLIs and PAPs. However, these constraints are rarely discussed directly, and critical analysis tends to address only low-level issues. Through simple literature searches, the IEG evaluation found several examples where outside parties, such as researchers, had raised critical views about the actual state of procurement and other fiduciary practices that do not seem to be reflected in the PforR assessments. Instead, the focus typically lies on institutional reforms to address corruption, including program-specific measures, often without presenting any convincing arguments that such measures will work in the case of the new programs. However, the IEG further notes, "interviews with team members during IEG missions confirmed their awareness of issues". The lack of published analysis is reportedly a result of borrower-government sensitivity (IEG 2016, xi, 31).48

In the case of the GIZ projects, it was difficult to assess the extent to which political economy analytical work was carried out, since it was not possible to review any project appraisal documents. ${ }^{49}$ Interviewee 3 pointed out, "we always have some trend analysis etcetera, but then I'm not al-

48 The IEG assessment noted that the Systematic Operations Risk-rating Tool introduced for PforR operations in January 2016 measures political and governance risk as one of nine risk categories. Another category measures the related aspect of institutional-capacity risk. It concludes, perhaps too optimistically, that "the use of this new tool is likely to address the political economy challenges raised in this report" (IEG 2016, 59).

49 On the Advanced Regionalisation Project, a PPT entitled Atelier global de planification opérationnelle du projet ARA - Présentation du projet ARA dated 25 
ways sure that in the end the analysis will be used in the practical work. I'm not sure if a 'peace and conflict' analysis exists, I've never seen it in Morocco". This stands in contrast to Interviewee 2, who asserted that for Tunisia, "of course we have our internal documents, and we conduct indepth peace and conflict, human rights, and gender analysis during project appraisal missions". Interviewee 2 explained that the BMZ usually formulates the country strategy based on political analysis performed by Germany-based academics, but that it is not very comprehensive for some countries - including Tunisia. This can be explained by the sudden rise of Tunisia as focus-country since the Arab spring and migration crisis. Indeed, "it still has B status, like a secondary country where we usually only work in two sectors with a limited range of projects, but it's actually one of the biggest portfolios in Germany development cooperation currently" (Interviewee 2). According to the same interviewee (Interviewee 2), mandatory risk management monitoring activities, where decisions are taken on the operational, country director, embassy or even ministry level, assure the quality of project implementation.

Indeed, even if a detailed analysis of the political economy of Moroccan decentralization/regionalization reforms existed, it would not have mattered in terms of selecting the four regions on which the GIZ project focused: The Ministry of the Interior decided on this matter, based on political party distribution (according to Interviewee 3). However, upon further probing, it seems that prior GIZ experience in some regions also played a role, for example in the Marrakesh-Safi region. The German development cooperation (also through the work of political party foundations, such as the Konrad Adenauer Foundation) had already set up a Maison de l'élu, which provides training for municipal and regional councilors. GIZ staff mostly seem to gather knowledge about the regions and their political and administrative representatives "on the job" (Interviewee 3). For Tunisia, Interviewee 2 also stressed the importance of relying on in-house political economy knowledge:

For the day-to-day analysis we are all dependent on our colleagues here in the country who work here and are part of the system, we have maybe one advantage, we have large teams on the ground [with Tunisian experts], who stay [...] in country, for a longer period of time

April 2019 was received from Interviewee 3. It was used to triangulate other data sources (i.e. websites and interviews). For the "Strengthening citizen-centred local government", the document entitled Jamaa Mouwatena - La participation citoyenne portée par les communes was provided by Interviewee 4 . 
than maybe if a project ends and another consultancy gets the contract and bring their staff. ${ }^{50}$

Indeed, the GIZ offices in Tunisia and Morocco are both very large: At the end of 2019, the GIZ office in Tunis had 303 national and 90 international employees. In Morocco, there were 271 national and 53 international employees. ${ }^{51}$ Similarly, GIZ staff in Tunisia are very well aware of the risk that their projects might be instrumentalized by political parties, such as the Ennahda party, which has attempted to profit from the central government's control over the local level. As Interviewee 2 observed,

mayors use donor projects like this to present themselves towards the political level and also in terms of being candidates for certain positions. So it's highly politicized, although you could think it's just a small project on citizen spaces; luckily it is not much about resources from our side, because our major contribution is technical advice, skills and we fund some renovation works, but we have a good experience until now.

To summarize, I found that the World Bank's (publicly available) analysis of the Tunisian situation is quite explicit regarding elite capture, while it is more technocratic and depoliticized in the Moroccan case. In both countries, the GIZ seems to rely mostly on political economy expertise found in-house and/or acquired on-the-job.

\section{Program implementation: Challenging or consolidating neopatrimonial networks?}

This section discusses the findings on the second research question: To what extent were the case study programs aware of neopatrimonial networks, and did they challenge or consolidate these networks?

50 In general, German development cooperation implemented by GIZ involves a high number of local senior experts including team leaders in the projects in the country who have the role of providing regular analysis. In addition, the M\&E system is conflict sensitive and includes Risk Monitoring (Interviewee 3, pers. Comm. 29 March 2021).

51 For the figures on Tunisia, see GIZ (2020b). For Morocco, see GIZ (2020a). Numbers could not be found for the World Bank country offices. See Honig (2020) for an interesting study on the effects of the World Bank's policy (part of the Strategic Compact) of increasing its country office staffing levels on project performance. 


\section{Findings from the World Bank program in Morocco}

For the Municipal Performance Program in Morocco, it is clear that the World Bank staff is aware of the challenges posed by the shift from a logic of control and discretion to one of transparency and performance. Introducing a performance framework which establishes a transparent and simple dashboard of what constitutes good municipal management, represents a challenge to the traditional organization in the DGCL based on sectoral divisions and silos (Interviewee 1). In order to overcome potential resistance and to build broad-based support (beyond the former wali of Casablanca, see above), the World Bank organized exchange visits with the individuals involved in the corresponding program for Tunisia. For example, a workshop featuring the head of the Tunisian CPSCL helped explain the program and generate buy-in on the Moroccan part, as it presented a clear model to follow (Interviewee 1). Indeed, the PAD acknowledges that the Municipal Performance Program was modelled largely on the World Bank's Urban Development and Local Governance PforR in Tunisia. It also mentions a study tour by Moroccan officials to Tunisia, which was organized in April 2019 to inform on the design of the operation (World Bank 2019a, 21). Interviewee 1 confirmed that this visit was organized for civil servants and a group of mayors representing all major political parties. It significantly contributed to increasing their motivation for and ownership of the program.

A further helpful factor was that the IGAT took on the role of independent verification agency required to verify the Disbursement Linked Indicators (DLIs). For the last eight years, the World Bank and IGAT have successfully worked on several programs together. IGAT's main organizational mission is to assess the management of local governments at the various (municipal, provincial and regional) levels in Morocco. Hence, it was easy for the civil servants working there to appropriate the annual performance assessment conducted as part of the PfoR program (Interviewee 1).

Apart from relatively technical areas, such as improved expenditure and revenue management, strengthened human resources, and improved service delivery ${ }^{52}$ the performance assessment framework also includes several criteria whose critical assessment determines whether performance-

52 This is done through citizen satisfaction measurement tools, the digitalization of key administrative services, and the improvement of municipal services, such as household waste collection, commercial licenses, and civil registry (World Bank 2019a, 21). 
based investment grants are allocated or not. These criteria have the potential to upset entrenched interests. They include standards of enhanced governance and transparency, such as citizen participation, the disclosure of key information, systematic measurement of citizen feedback, and implementation of the right to petition at the level of municipalities. Social and environmental management criteria also include "political" aspects. Examples are the effective functioning of the consultative group on equity, equality of opportunities, and gender sensitive approaches (Instance de l'Equité, de l'Egalité des Chances et de l'Approche Genre, IEECAG), and the adoption of a planning process that identifies and addresses the specific needs of women and men in infrastructure and service delivery (World Bank 2019a, 21).

Although the World Bank loan was only approved by the World Bank's Board in November 2019 and became effective in April 2020, the DGCL launched an initial round of annual performance assessments already in May 2019. Initial results of the performance assessment were presented and discussed with the participating municipalities in a series of regional workshops held in July 2019. The objective of this initial round was to establish the new performance-based approach ahead of the 2021 elections (World Bank 2019a, 22). The PAD identified the main political risk as being

related to the municipal council renewal following the elections that will be held in 2021, during the first phase of the Program cycle. Specifically, non-incumbent elected municipal authorities will need to be rapidly familiarized with the Program in the post-election period. To mitigate these risks, the Program will account for electoral incentives and risks in the design and choice of MMCs, PIs, and PAPs. In addition, ad hoc consultations and capacity-building activities with incoming municipal authorities will help build buy-in and understanding of the opportunities of the Program.

According to Interviewee 1, the 2019 cycle was carried out through self-assessment and online documentation by municipalities without on-site verification, yet it was still possible for the DGCL to roughly assess whether the data was reliable or not, given their own information systems. The 2019 cycle was a test-round rather than a fully-fledged assessment, in order to acquire a sense of where the municipalities stand on the different indicators. The World Bank and the Ministry of the Interior agreed that it was important to start disbursing the grants to the municipalities well before the 2021 elections, in order to avoid any suspicion of the Ministry of the Interior trying to influence them (Interviewee 1). 
The formula for allocating the funds to the 100 municipalities in the program is straightforward. A share of 30 to $40 \%$ of the total amount is divided equally between all municipalities; the remainder is distributed proportional to the population size according to the 2014 census. If a municipality does not meet any of the five minimum criteria, it will not receive any funds. If it meets all minimum criteria, it receives $40 \%$ of its envelope; the rest is dependent on its performance score. Furthermore, if a municipality does not receive anything in the first year, its share is transferred to the following year. This increases the incentive for the municipality to improve its performance (Interviewee 1).

At the workshops held in July 2019, the municipalities' scores on meeting the MMCs were presented, and the DGCL announced that those municipalities who had not yet met the MMCs would be granted three or four further months to meet them. According to Interviewee 1, "it worked surprisingly well. Only 11 municipalities had met the 5 minimum conditions in May, and I think 87 of them did by November". ${ }^{53}$ All Minimum Mandatory Conditions are legal obligations, such as the publication of financial statements (stipulated in the 2015 organic law on municipalities). Hence, Interviewee 1 asserts that this result is "a sea change that they were able to drive with a relatively modest amount of money, because the envelope allocated is 200 million DH, so it's 20 million dollars for 100 municipalities, so it's not huge". 54

The potential of the Municipal Performance program to disrupt entrenched tutelle practices by the DGCL are thus significant. It tries to establish grants unencumbered by restrictions, apart from being designated for investment. In other words, the program tries to make the central state of Morocco shift from a logic of tutelle to one of accompagnement, despite the fact that many of the civil servants at the DGCL remain in their positions, and must hence undergo a shift in mindset. Therefore, the program staff had to insist that once the grants are transferred to the municipalities, it is the responsibility of the municipal council to take all decisions related to appropriating and spending the funds, without prior approval by the DG-

53 However, although the preliminary results of the CY19 performance assessment cycle indicate that $83 \%$ of participating municipalities have met the MMC, compared to an initial target of $60 \%$ in 2020 , this is yet to be verified by the Independent Auditor (IGF). Implementation Status \& Results Report Municipal Performance Program (P168147), dated 2 March 2021 (World Bank 2021, 7).

54 Almost all 100 municipalities have their performance and financial statements published on the website Performance Communes, https:/www.performancecommunes.ma/fr/public/ (Interviewee 1). 
CL or any other form of tutelle. The latter would mean a perpetuation of the old system, in which every (small) grant and disbursement requires the municipality to submit documentation to the provincial office, with sometimes uncertain outcome or follow-up (Interviewee 1).

However, due to the Covid-19 pandemic, the 2019 performance grant transfers have not yet taken place. In August 2020, the DGCL sent letters to the municipalities informing them of the amount allocated to them. This amount was supposed to be transferred before the end of the 2020 budget cycle. Some municipalities receiving the letters started informing the press. This raised suspicion over attempted influence on the elections, forcing the DGCL to react by explaining that the program is meant to evaluate municipal administration every year, even after the elections. On the other hand, the letters also stimulated some healthy competition between municipalities, e.g. mayors using Twitter to announce proudly that they would receive a grant to reward them for good performance (Interviewee 1).

It is too early to say whether this program will reduce the discretion over intergovernmental transfers on the part of the Ministry of the Interior. For example, one of the DLIs includes the provision that "The Ministry of Interior has updated the rules and regulations governing fiscal transfers to municipalities and included the performance grant window as an integral part of the fiscal transfer framework", yet this is not due until 1 July 2021. In addition, the COVID-19 crisis and the imposed lockdown restrictions delayed the launch of the 2020 performance assessment (World Bank 2020a, 4). However, it seems that the World Bank is optimistic that the municipalities will achieve the DLIs, since the political and governance risk has been downgraded from substantial to moderate. This occurred because "training modules are being developed to familiarize municipalities and the incoming elected officials with the system, its process and benefits, thus mitigating the risks of post-election (in 2021) issues in the roll-out of the municipal performance assessment" (World Bank 2020a, 6; see also World Bank 2021, 6; it is not clear what exactly is meant by "issues").

\section{Findings from the World Bank program in Tunisia}

As for the World Bank's program in Tunisia, change occurred in three arenas. First, the reform of the block grant system clearly reduces the central government's discretion in the area of fiscal transfers. In the past, the government used to negotiate with municipalities on their budget requirements and they would have to submit a list of specific projects that they 
wanted to finance (Interviewee 5). Not surprisingly, the reforms of the fiscal decentralization system encountered resistance at multiple fronts and from various stakeholders. For example, there was resistance to the idea of de-linking the capital grants transfer from the obligation of municipalities to borrow simultaneously from the CPCL. The institutions and civil servants involved feared a curtailing of their roles and of the extent to which they could control the local level through this system: "There was a lot of resistance [and they asked], 'what is the caisse going to become [...] if it doesn't do credit anymore?'. [...] [We told them that] if a municipality wants to take credit then you have to provide them that service but you cannot condition the grant transfer to credit, and this was a big combat at the institutional level" (Interviewee 5).

Resistance also formed against the shift to performance-based capital grant transfers. Some policy-makers believed that in a post-revolution country embracing decentralization, a performance-based system of transferring funds to municipalities would interfere with the principle of municipal autonomy. Simultaneously, some stakeholders in the central administration wanted to uphold the discretionary element in deciding on municipal finances. In the words of Interviewee 5,

Tunisia is a very administratively ruled country; it's not a politically ruled country; the administration is really powerful. [...] I think politicians who rightfully thought that the decentralization process is the main pillar of the new social contract in Tunisia didn't know the details of it. [...] When you have a lack of knowledge and understanding of what the decentralization process must look like and how you should move it forward, [...] I think that's where the disconnect happens and that's where the administration takes over. [...] That's what we are facing today very clearly again.

Referring to the current inertia, Interviewee 5 added that the new system was put in place during a unique "flection point", when decentralization rather than economic transformation - was seen as the main pillar of reinventing the social contract post-revolution. The same interviewee claimed that it would be hard to reverse these reforms now.

The second arena of change is at the level of municipalities themselves. The new portail des collectivités locales includes all the financial information and performance indicators for each municipality, which has spurred a competitive dynamic. In the words of Interviewee 5:

A lot of healthy competition is happening [...]. This data helped create a real transformation after elections, which means that as new munici- 
pal councilors and new mayors arrived, they looked at their data of 2016-2017 and said 'really? We didn't achieve our performance, we missed 10 million Dinar for some stupid reason, we didn't publish our procurement plan, or we didn't share our budget on time, or we didn't do this...?' So we saw a lot of municipalities shift 180 degrees [and climb up the rankings quickly]. [...] So I think it worked very well and it was primarily a great instrument for mayors and municipal councils to get more resources for their municipalities and also to show that they actually managed to transform the performance of their municipality by their arrival. So that I think is a great achievement, you know, 'I'm elected, I have a team with me, I have an institution with me as well which is the municipality, and I can make a difference, I can shift things around.' And that's important.

Asked whether the portal is being used by the public at large, Interviewee 5 replied that it is visited by NGOs, civil society and also individuals who are interested, although not yet by the ordinary citizen. ${ }^{55}$

The third arena of change concerns the relations between municipalities and citizens, which have been reformed through the program's conditions around transparency. This includes, for example, the obligatory conduct of public hearing meetings and reporting to citizens on the budgeting and implementation of municipal projects. In addition, all municipalities are audited yearly by the Cour des Comptes [National Court of Audit], which is an entirely new measure. Interviewee 5 further pointed out that "publishing the procurement plan is extremely important, $[\ldots]$ because you just can't give the same enterprise 12 contracts for 12 years in a row. People are looking into those things and start seeing that, 'ah okay, there are anomalies". .56

55 The Implementation Status \& Results Report TN-Urban Dev. and Local Governance (P130637) dated 28 October 2020 (World Bank 2020b, 14) mentions that "From January to April 2020, we witnessed a 300\% increase in monthly users on the LG portal (15,000 monthly users) compared to the same period last year".

56 This positive outlook contrasts with the assertion by the well-reputed NGO AlBawsala, which concluded that the "national transparency rate" at the municipal level (essentially determined by the positive responses to request for access to information) had declined significantly between 2018 and 2019. This, however, could also be a result of the high number of new municipalities that were created during that period (see L'Economiste Maghrébin 2020). 
Although the World Bank's leverage cannot be compared with that of the GIZ (see footnote 17), it is clear that the way the German development cooperation has divided the roles between the GIZ and the German Development Bank (KfW) - among other German actors - means that the GIZ is not directly involved in policy decisions. More research is needed on the exact nature of the relationship between the GIZ and KfW. However, it seems that the GIZ's technical assistance is not directly linked to loans contracted by the KfW, as is the case with donors such as the World Bank, the French Development Agency and others. As Interviewee 5 put it, these latter donors "leverage well their two arms of their intervention - so they would work on a loan and then while preparing the loan, you could shake a lot of things. While if you are just doing a TA you can rarely do things in a transformative manner. You could eventually help and support, and do studies but when you reach to the negotiations table you don't have leverage". Interviewee 2 concurred by saying "if a [GIZ] project of 5 million is not funded anymore, it will not really harm any decision-maker in the government, but if you talk about 400-500 million euros, that's something". 57

The GIZ's limited leverage was indirectly referenced by Interviewee 3, speaking on the GIZ project on advanced regionalization in Morocco. He explained that at the beginning,

these four regions [i.e. Casablanca-Settat, Marrakesh-Safi, Oriental and Souss-Massa] were very interested [to be part of our project], but they mixed something up, they thought GIZ was a big donor who would put in a lot of money for regional development. Of course, this is a misconception, because we were there to promote good governance, and capacity building in the region, and promote citizen participation and things like that. [...] But they accepted it, there was generally no problem.

More importantly, the GIZ project on advanced regionalization stands apart from the DGCL itself. As Interviewee 3 explained, "in the beginning, it was also [stated] in the project proposal to go into monitoring of the regionalization process on a country-wide level within the ministry. They didn't want it at all, they said, 'o.k. you can do monitoring but for the re-

57 According to Furness (2020, 81), officials in the BMZ and other ministries are working to bring about the closer alignment of technical co-operation projects with the large financial co-operation initiatives in Tunisia. 
gions [only]'." The GIZ's influence is arguably also limited because of the way that the advanced regionalization process is organized in Morocco, and in particular, due to the artificial separation between decentralization and deconcentration processes. Interviewee 3 explained that "for me it's clear that if you start decentralization you need also this deconcentration, and then I learnt quickly that it is completely separated, there is another Ministry at the front of this process, and I [was told that I] should not care about it." 58

When it comes to supporting citizen participation, the GIZ project on advanced regionalization has partnered with the National Democratic Institute (NDI) to support the consultative committees (instances consultatifs), which are mentioned in the organic law of the regions. ${ }^{59}$ However, GIZ and NDI are unable to prevent the co-optation of some civil society members or the exclusion of others. Regional council members often claim the right to decide on membership, frequently appointing themselves in the process, which is contrary to the purpose of these committees. They are supposed to monitor the work of the regional councils and give independent inputs. In some regions, consultative committee members are not even allowed to enter the regional council building in order to attend meetings (Interviewee 3).

For its part, the GIZ project on 'strengthening citizen-centered local government' in Morocco contributed to increasing scrutiny by the citizens over municipal affairs through establishing complaint mechanisms inside its partner municipalities. A satisfaction survey conducted as part of the project showed high levels of perceived (financial) corruption or related practices, such as favoritism and the mixing of roles and functions. The latter issue refers to the conflict of interest that stems from the fact that many councilors also head local associations and hence may use their access to municipal funds to support their own associations (see also Bergh (2017)). This situation led the GIZ to not work with organized civil society groups, but rather with individual citizens (Interviewee 4). This high level of

58 As Vollmann et al. (2020, 24-25) argue, "regional dependency on central government transfers has increased after the reforms and tight staffing impedes the potential for an autonomous implementation of projects. The de facto strong supervision by the Ministry of Interior represents strict central control mechanisms for the implementation of reforms" (see also Bergh (2021) for a similar argument).

59 There are three such consultative committees: One is related to the principals of equity, equality of opportunities, and gender sensitive approaches; one is related to youth; and one is related to economic affairs (see Article 117 in Royaume du Maroc 2016). 
awareness of corrupt practices among citizens is arguably a promising sign that they are or will be using the complaint mechanisms to expose them.

Indeed, a related issue the GIZ addressed in Morocco is that municipalities need to become more able to respond to increased citizen engagement. Both the administrative staff and councilors were - and still are - afraid of stressful encounters and confrontations with citizens. The project thus ran trainings for the reception staff (le personnel de l'acceuil communal) on how to engage with citizens and on how to successfully perform conflict management and mediation. According to Interviewee 4, the project was successful in mitigating these tensions by creating a competence pool of individuals trained in communication with the public and on participatory measures in seven municipalities.

\section{Findings from the GIZ's project in Tunisia}

A similar dynamic occurred within the GIZ's project in Tunisia, which has thus far created 13 citizen offices. In the words of Interviewee 2,

so it sounds very operational, the idea of citizen office, but it touches on information and power-base, both on the local and national level. If you re-organize a municipality, not letting in the citizens to every office anymore, this touches existing structures in terms of corruption, so you reduce the possibility for each and every agent in each and every step of a procedure to take bribes, you create transparency, and this can really touch local power structures.

Finally, the GIZ's project in Tunisia also seems to have empowered the municipalities vis-à-vis the central administration. As Interviewee 2 explained, due to the change in the legal framework (self-determination),

municipalities can [now] decide on their own whether they want to open up a citizen office and how to organize themselves and this has touched very much the former comprehension of political leaders that if the Ministry of Local Affairs or the Interior says something, the municipalities have to follow. [...] It was also a learning process for the decision makers, as questions were asked, 'Are we allowed to do this? And how does it fit in our organigram which has maybe been advised by the ministry, because it's totally different?' [...]. Currently we have 60-70 cities who demand a citizens office, but it is not yet in the official government policy, so it is our task right now to work on a scaling up strategy to include it in public policies at the national level. 
Indeed, the GIZ also helps municipalities and the federation of cities to lobby the central government, by conducting evaluations of the performance of citizen offices in order to prove that they have a positive impact.

\section{Summary of findings}

The findings presented here demonstrate that the implementation of the two World Bank programs clearly threaten the discretionary power and entrenched ex-ante tutelle practices held by central administration staff, especially in the area of fiscal transfers. They also provide strong incentives for municipalities to comply with transparency-enhancing legal obligations, such as the publication of financial statements. There are furthermore signs that they encourage a healthy competition between municipalities. While this chapter did not examine the BMZ's leverage over the decentralization reforms (e.g. through loans provided by the KfW), it seems that the GIZ's technical expertise and significant staffing does not translate into real influence on the reform implementation process, although it provides important support to strengthen state-society relations at the local level. The GIZ projects analyzed here seem to have contributed to higher levels of scrutiny by citizens over municipal affairs, thereby interfering with existing structures of corruption, and to increased empowerment of the municipalities vis-à-vis the central administration.

\section{The extent of donor coordination, and technical assistance overload?}

The third research question inquires about the extent of donor coordination around the decentralization reforms, which would minimize the risk of fragmentation and duplication as well as of national stakeholders "playing off" various donors against each other to maximize their benefits without committing to fundamentally challenging the elites' vested interests.

In Morocco, the GIZ project on municipalities has worked closely with the World Bank program. As interviewee 4 explains, "some of the things we helped our municipalities get to do regarding, for example, the satisfaction surveys or complaints mechanisms is something that is part of the World Bank indicators. And almost all our partner municipalities are now part of the hundred municipalities which are within the Bank's program". However, in general, we know that donor coordination is hampered by the fact that the DGCL seems to prefer to keep each donor isolated from 
others (see Bergh 2016, 13). In other words, it is possible that the regime's strategy regarding donors is similar to its strategy vis-à-vis domestic elites, i.e. "divide and rule". 60

In Tunisia, most of the municipalities in which the GIZ works are also part of the World Bank's program (Pers. Comm. Interviewee 2 on 29 March 2021). In general, there seems to be a shared vision between different donors, not least because the decentralization process in Tunisia is still very basic. As Interviewee 5 observed, "we are not thinking very creatively about sophisticated details yet, we are really in the foundation of it and in the foundation you can't disagree much at this point in time". This was confirmed by Interviewee 2, especially regarding donor coordination around support for the newly created municipalities. ${ }^{61}$

However, the sheer volume of technical assistance for decentralization, at least in Tunisia, could become problematic. As Interviewee 5 pointed out:

There is an overburden today in Tunisia with a lot of technical assistance. There are millions and millions of dollars thrown into the decentralization process in terms of technical assistance. I think there is a fatigue of that and there is a confusion. [...]. There's too much of it and there is limited government absorption capacity. You need to multiply your government by 20 to be able to absorb all those studies and TA and consultants roaming around on this topic. [...] You know, the donor community loves this topic, as we said it's part of the social con-

60 According to Vollmann et al. $(2020,7)$, the regime encourages political competition through decentralization reforms as part of a broader strategy to balance power relations between elites on all levels of government. The 2004 OECD-DAC study on donor support to decentralization (OECD 2004, 10) concluded that donor coordination is generally considered weak, both at national and local government levels. This is due to the common belief that donor co-ordination should be the government's responsibility rather than that of donors themselves, the need for agencies to deliver a readily identifiable product, and governments' preference of dealing with donors on an individual basis (see also Ismail $(2019,6)$ on the fragmentation of donor technical assistance in North Africa).

61 However, the 2019 CoMun evaluation report (GIZ 2019, 8) notes an example of incompatibility between GIZ and the World Bank projects, as the "sustainability of the [participatory budgeting] instrument is threatened by a conflict with the CPSCL, which regards the participatory budgets supported by GIZ as incompatible with the conditions it has established jointly with the World Bank for municipalities wishing to draw on funds from the Bank's Programme for Urban Development and Local Governance that is implemented countrywide”. 
tract, part of voice and accountability, I understand why they love it but I think they are loving it too much.

The Tunisian government's reaction is arguably one of disbelief at the sheer amounts involved, but it has limited leverage in redirecting the funds to funding municipal investments themselves as TA mostly comes in the form of grants, not loans, and it may see the benefits in terms of local employment creation. Interviewee 5 concluded by saying that "for the country, there needs to be a rethought about of how we support the decentralization process, how do we leverage each other effectively, that's extremely crucial”.

\section{Conclusion}

This chapter explored the role of two dominant external actors in the decentralization reforms in Morocco and Tunisia, namely the World Bank and the GIZ, and the extent to which they "Think and Work Politically" (TWP). Regarding elite capture, in its design stage the World Bank's analysis (as reflected in the Program Appraisal Documents) is quite explicit for Tunisia, while it uses more technocratic and depoliticized language in the Moroccan case. The GIZ seems to rely mostly on political economy expertise found within its large pool of local staff as well as expertise acquired on-the-job by its international staff, especially in the Moroccan case.

The findings of this chapter moreover demonstrate that through their focus on removing ex-ante tutelle practices held by central administration staff in the area of fiscal transfers, the implementation of the two World Bank programs very likely disrupts neopatrimonial networks. Through their PforR aid modality and significant financial size, the programs also provide strong incentives for municipalities to comply with transparencyand accountability- enhancing legal obligations. On the other hand, as an implementing agency providing technical assistance only, the GIZ's projects operate predominantly at the "local" level of the central-local relations. By providing important support to strengthening the "demand-side" of accountability within decentralization reforms, for example through setting up citizen bureaus, the GIZ projects have the potential to interfere with existing local structures of corruption. The programs and projects reviewed here thus reflect the conceptual distinction that "making decentralization work is about more than just supporting local governments; it is about strengthening the system of governance in which decentralized governments take part" (Dickovick 2013, 7); whereby the GIZ focuses more 
on the former and the World Bank on the latter. By including important components of downward accountability through different types of interventions, both actors' interventions arguably contribute to mitigating the risk that decentralization leads to the reconstruction of clientelism at the local level in both countries (Eaton et al. 2011, 24).

Evidence for the third research question is more limited. In both countries, the broad geographical coverage of the World Bank programs includes most of the municipalities participating in GIZ projects. It appears that when decentralization processes are at a more "basic" stage, donor coordination is stronger (and the ability of the government to play off various donors therefore weaker). Thus, donor coordination in Tunisia is more pronounced than in Morocco. Particularly in Tunisia, the issue of an overload of technical assistance at the expense of funding municipalities themselves was raised as an urgent concern. However, this focus on technical assistance could also be a deliberate strategy by donors to minimize the risk for political manipulation and neopatrimonial exploitation of their involvement.

By analyzing the mechanisms of the donor programs and their relative influence on entrenched local interests, the chapter further nuances (and updates) the argument made by Vollmann et al. $(2020,26)$ that the reforms in Morocco (and Jordan) "may have helped to appease protesters and threats from the periphery for a while [...but that] a potential drive for change is hindered by a vast fiscal dependency of decentralized institutions on central state transfers, the enduring de jure and de facto control on behalf of the center, as well as by the strong presence of subnational elite circles that are primarily mirroring central elite compositions". Indeed, the authors conclude rather pessimistically and categorically that "so far, the implementation of decentralization reforms in Jordan and Morocco contributed to authoritarian upgrading rather than an empowerment of subnational autonomy in the sense of western donors' and civil society activists' expectations". ${ }^{62}$

The findings presented in this exploratory chapter show that the World Bank (with support from other donors, including Germany) is aware of the local political context in both Morocco in Tunisia, and is utilizing the significant loan volumes to exercise considerable leverage on changing center-periphery relations towards more autonomy for municipalities. These findings appear evident despite the limited available data, and des-

62 See also Khakee (2018) for case studies on illustrating the complex mechanisms linking democracy aid and hybrid regime strengthening in the Moroccan case. 
pite the fact that Morocco and Tunisia - like many countries in the region - are using the Covid-19 pandemic as an excuse to re-centralize certain powers under emergency rule. ${ }^{63}$ A further finding is that while the GIZ is not as centrally involved in key political economy aspects, due to the limited mandate granted by the BMZ, its work on the "demand" side of cooptation holds significant potential to generate civilian scrutiny of local patron-client relations. Particularly the establishment of citizen offices may strengthen accountability mechanisms and curb the tolerance toward corrupt behavior.

\section{References}

Aliriza, Fadil. 2018. "Decentralization in Tunisia: Its Utility and Competing Visions for Implementation." In The Arc of Crisis in the MENA Region: Fragmentation, Decentralization, and Islamist Opposition, edited by Karim Mezran and Arturo Varvelli, 37-48. Milan: Italian Institute of International Political Studies (IPSI) and Atlantic Council.

Andrews, Matt. 2015. "Explaining Positive Deviance in Public Sector Reforms in Development.” World Development 74: 197-208. doi: 10.1016/j.worlddev.2015.04 .017 .

Baccouche, Néji. 2016. "Decentralization in Tunisia: Challenges and Prospects." In Federalism: A Success Story? International Munich Federalism Days 2016, edited by Hanns Bühler, Susanne Luther, and Volker L. Plän, 183-197. Munich: Hanns Seidel Stiftung.

Bachir, Malek. 2021. "Germany - Morocco tensions: Why is Rabat so Upset with Berlin?” Middle East Eye, March 5. Accessed March 31, 2021. https:/www.middl eeasteye.net/news/germany-morocco-tensions-why-rabat-so-upset-berlin.

Bel Haj Amor, Mohamed Lamine. 2020. "Local Governance in Tunisia - A Holistic Decentralisation Strategy" In Tunisia's Fragile Democracy: Decentralization, Institution-Building and the Development of Marginalized Regions: Policy Briefs from the Region and Europe. DGAP Report No. 2., edited by Dina Fakoussa and Laura Lale Kabis-Kechrid, 13-15. Berlin: Forschungsinstitut der Deutschen Gesellschaft für Auswärtige Politik e.V.

Bellamine, Yassine. 2015. "Gouvernance locale: Quand la Banque Mondiale s'Immisce dans la Gestion de nos Municipalités.” Nawaat, February 3. Accessed March 31, 2021. https://nawaat.org/2015/02/03/gouvernance-locale-quand-la-ban que-mondiale-simmisce-dans-la-gestion-de-nos-municipalites/.

Bellin, Eva. 2012. "Reconsidering the Robustness of Authoritarianism in the Middle East. Lessons from the Arab Spring.” Comparative Politics 44 (2): 127-149. doi: $10.5129 / 001041512798838021$. 
Bergh Sylvia I. 2012a. "Introduction: Researching the Effects of Neoliberal Reforms on Local Governance in the Southern Mediterranean.” Mediterranean Politics 17 (3): 303-321. doi: 10.1080/13629395.2012.725299.

Bergh, Sylvia I. 2012b. “'Inclusive' Neoliberalism, Local Governance Reforms and the Redeployment of State Power: The Case of the National Initiative for Human Development (INDH) in Morocco.” Mediterranean Politics 17 (3): 410-426. doi: 10.1080/13629395.2012.725304.

Bergh, Sylvia I. 2016. "Public Sector Governance Reforms and 'Advanced Regionalization' in Morocco: What Role for the European Union?” EUI/RSCAS Working Paper 56, commissioned by the BORDERLANDS Project. Accessed March 31, 2021. http://cadmus.eui.eu/handle/1814/43984.

Bergh, Sylvia I. 2017. The Politics of Development in Morocco: Local Governance and Participation in North Africa. London and New York: I.B. Tauris.

Bergh, Sylvia I. 2020. "Morocco's Decentralization Experience.” In The Dynamics of Decentralization in the MENA: Processes, Outcomes, and Obstacles. The Program on Governance and Local Development (GLD) Working Paper 31, edited by Marwa Shalaby, Chagai Weiss, Ellen Lust, Kristen Kao, Erik Vollmann, Sylvia I. Bergh, Ezra Karmel, Miriam Bohn, Intissar Kherigi, and Zeynep Kadirbeyoglu, 23-39. Gothenburg: GLD.

Bergh, Sylvia I. 2021. "Democratic Decentralization and Local Development: Insights from Morocco's Advanced Regionalization Process" In Research Handbook on Democracy and Development, edited by Gordon Crawford and Abdul-Gafaru Abdulai, 482-502. Cheltenham: Edward Elgar. doi: 10.4337/9781788112659.000 39.

Berthin, Gerardo. 2018. “The Role of Donors in Strengthening Local Governments and Decentralization: Lessons from Colombia and Peru.” Paper prepared for delivery at the 2018 Congress of the Latin American Studies Association May 2326, 2018, Barcelona, Spain. Accessed March 31, 2021. https:/www.academia.edu /37139607/The_Role_of_Donors_in_Strengthening_Local_Governments_and_ Decentralization_Lessons_from_Colombia_and_Peru.

BMZ. 2021a. "Länder.” Accessed March 31, 2021. https:/www.bmz.de/de/laender.

BMZ. 2021b. "TUNISIA. Country in Transition.” Accessed March 31, 2021. https:// www.bmz.de/en/countries/tunisia.

Booth, David, and Sue Unsworth. 2014. "Politically Smart, Locally Led Development”, ODI Discussion Paper, London: Overseas Development Institute. Accessed March 31, 2021. http://www.odi.org/sites/odi.org.uk/files/odi-assets/publi cations-opinion-files/9158.pdf.

Burnell, Peter, and Oliver Schlumberger. 2010. "Promoting Democracy - Promoting Autocracy? International Politics and National Political Regimes." Contemporary Politics 16 (1): 1-15. doi: 10.1080/13569771003593805.

Bunk, Bettina. 2018. "The Dynamics of Donor and Domestic Elite Interaction in Mozambique: Formal Decentralisation and Informal Power Structures." Conflict, Security \& Development 18 (4): 321-346. doi: 10.1080/14678802.2018.14 83555. 
Carothers, Thomas, and Diane de Gramont. 2013. Development Aid Confronts Politics: The Almost Revolution. Washington, DC: Carnegie Endowment for International Peace.

Dasandi, Niheer, Heather Marquette, and Mark Robinson. 2016. "Thinking and Working Politically: From Theory Building to Building an Evidence Base.” DLP Research Paper 37. Birmingham: Developmental Leadership Program, University of Birmingham. Accessed March 31, 2021. https://res.cloudinary.com/dlprog/i mage/upload/UYhaGQDT51Zo7EbvF52hTvFCSFlyMRtKGOgv7rhL.pdf.

Demmelhuber, Thomas, Roland Sturm, and Erik Vollmann. 2020. "Decentralization in the Arab World: Conceptualizing the Role of Neopatrimonial Networks." Mediterranean Politics 25 (4): 499-521. doi: 10.1080/13629395.2018.1559 391.

Denney, Lisa, and Pilar Domingo. 2017. "Political Economy Analysis: Guidance for Legal Technical Assistance.” London, UK: ROLE UK. Accessed March 31, 2021. https://www.roleuk.org.uk/sites/default/files/files/2019\%20-020PEA\%20\%20Guidance\%20for\%20legal\%20technical\%20assistance.pdf.

Dickovick, J. Tyler. 2013. Foreign Aid and Decentralization: Policies for Autonomy and Programming for Responsiveness (No. 2013/044). WIDER Working Paper.

Eaton, Kent, Kai Kaiser, and Paul J. Smoke. 2011. The Political Economy of Decentralization Reforms: Implications for Aid Effectiveness. Washington, DC: The World Bank.

Fritz, Verena, and Brian Levy. 2014. "Problem-Driven Political Economy in Action: Overview and Synthesis of the Case Studies." In Problem-driven Political Economy Analysis: The World Bank's Experience, edited by Verena Fritz, Brian Levy, and Rachel Ort, 1-30. Washington D.C.: The World Bank.

Furness, Mark. 2020. “'Donorship’ and Strategic Policy-making: Germany’s Middle Eastern and North African Aid Program since the Arab Uprisings." Development Policy Review 38 (1): 70-90. doi: 10.1111/dpr.12461.

Gelb, Alan, and Nabil Hashmi. 2014. "The Anatomy of Program-for-Results: An Approach to Results-Based Aid.” CGD Working Paper 374. Washington, DC: Center for Global Development. Accessed March 31, 2021. http://www.cgdev.or $\mathrm{g} /$ publication/anatomy-program-results-approach-results-based-aidworking-pape r-374.

GIZ. 2017. "Tunisia: Supporting Regionalisation: Project Evaluation: Summary Report.” Bonn/Eschborn: Deutsche Gesellschaft für Internationale Zusammenarbeit (GIZ). Accessed March 31, 2021. giz2017-0002en-projectevaluation-tunisia -regionalisation-pev.pdf.

GIZ. 2019. "Strengthening Municipal Development and Democracy in the Maghreb (CoMun): Project Evaluation: Summary Report.” Bonn/Eschborn: Deutsche Gesellschaft für Internationale Zusammenarbeit (GIZ). Accessed March 31, 2021. giz2019-0099en-projectevaluation-comun-maghreb-pev.pdf.

GIZ. 2020a. "Marokko.” Accessed March 31, 2021. https://www.giz.de/en/worldwi de/340.html.

GIZ. 2020b. “Tunisia.” Accessed March 31, 2021. https://www.giz.de/en/worldwide /326.html. 
GIZ. 2021a. "Democracy at the Local Level.” Accessed March 31, 2021. https://ww w.giz.de/en/worldwide/38695.html.

GIZ. 2021b. "Digital Municipalities in Tunisia: Transparent, Citizen-oriented and Efficient.” Accessed March 31, 2021. https:/www.giz.de/en/worldwide/31897.ht $\mathrm{ml}$.

GIZ. 2021c. "More Regional Responsibility.” Accessed March 31, 2021. https://ww w.giz.de/en/worldwide/81969.html.

GIZ. 2021d. "Support for Decentralisation in Tunisia.” Accessed March 31, 2021. https:/www.giz.de/en/worldwide/73233.html.

Harb, Mona, and Sami Atallah. 2015. "A Framework for Assessing Decentralization in the Arab World." In Local Governments and Public Goods: Assessing Decentralization in the Arab World, edited by Mona Harb, and Sami Atallah, 110. Beirut: LCPS.

Holthaus, Leonie. 2019. "Is there Difference in Democracy Promotion? A Comparison of German and US Democracy Assistance in Transitional Tunisia." Democratization 26 (7): 1216-1234. doi: 10.1080/13510347.2019.1618832.

Honig, Dan. 2020. "Information, Power, and Location: World Bank Staff Decentralization and Aid Project Success.” Governance 33 (4): 749-769. doi: 10.1111/ gove. 12493 .

Hout, Wil. 2012. "The Anti-Politics of Development: Donor Agencies and the Political Economy of Governance.” Third World Quarterly 33 (3): 405-422. doi: 10.1080/01436597.2012.657474.

Hudson, David, and Adrian Leftwich. 2014. "From Political Economy to Political Analysis.” DLP Research Paper 25. Birmingham: Developmental Leadership Program, University of Birmingham. Accessed March 31, 2021. http://publicatio ns.dlprog.org/From\%20Political\%20Economy\%20to\%20Political\%20Analysis.p df.

Hudson, David, Claire McLoughlin, Heather Marquette, and Chris Roche. 2018. Inside the Black Box of Political Will: 10 Years of Findings from the Developmental Leadership Program. Birmingham: Developmental Leadership Program, University of Birmingham.

Independent Evaluation Group (IEG). 2016. Program-for-Results: An Early-Stage Assessment of the Process and Effects of a New Lending Instrument. Washington D.C.: The World Bank.

Ismail, Zenobia. 2019. Technical Assistance and Capacity Building in International Development. K4D Helpdesk Report. Birmingham UK: University of Birmingham.

KfW. 2021a. “Marokko.” Accessed March 31, 2021. https://www.kfw.de/microsites/ Microsite/transparenz.kfw.de/\#/country/MAR.

KfW. 2021b. “Tunesien.” Accessed March 31, 2021. https:/www.kfw.de/microsites/ Microsite/transparenz.kfw.de/\#/country/TUN.

Khakee, Anna. 2017. "Democracy Aid or Autocracy Aid? Unintended Effects of Democracy Assistance in Morocco.” The Journal of North African Studies 22 (2): 238-258. doi: 10.1080/13629387.2017.1279971. 
Kherigi, Intissar. 2020. “Tunisia's Decentralization Reforms: The Gap between Ideas and Implementation." In The Dynamics of Decentralization in the MENA: Processes, Outcomes, and Obstacles, edited by Marwa Shalaby, Chagai Weiss, Ellen Lust, Kristen Kao, Erik Vollmann, Sylvia I. Bergh, Ezra Karmel, Miriam Bohn, Intissar Kherigi, and Zeynep Kadirbeyoglu, 54-66. Gothenburg: GLD.

L'Economiste Maghrébin. 2020. "Al-Bawsala: Régression du taux de Transparence dans les Municipalités.” L'Economiste Maghrébin January 17, 2020. Accessed March 31, 2021. https:/www.leconomistemaghrebin.com/2020/01/17/al-bawsala -regression-du-taux-de-transparence-dans-les-municipalites/.

Loibl, Franziska, Luca Eckermann, and Lukas Marx. 2020. "Digital Municipalities in Tunisia: Transparent, Citizen-oriented and Efficient." Accessed March 31, 2021. https://www.giz.de/en/downloads/Factsheet-EN_TUN-Kommunalentwick lung_Stand\%2007-2020_LE.pdf.

Magri, Paolo. 2020. "Holding Back the Old Demons in the Euro-Mediterranean Region in Post-pandemic Times: Populism and Authoritarianism in Dossier: An Unexpected Party Crasher: Rethinking Euro-Mediterranean Relations in Corona Times, 25 Years after the Barcelona Process.” In Mediterranean Yearbook 2020, edited by IEMed, 119-124. Barcelona: IEMed.

OECD. 2004. Lessons Learned on Donor Support to Decentralisation and Local Governance. Paris: OECD.

Performance Communes. 2021. "Direction Générale des Collectivités Territoriales. Programme d'Appui à l'amélioration de la Performance des Communes au Maroc.” Accessed March 31, 2021. https://www.performancecommunes.ma/fr.p hp.

POMEPS. 2020. "The COVID-19 Pandemic in the Middle East and North Africa" The Project on Middle East Political Science - POMEPS Studies April 39, 2020. Accessed March 31, 2021. https://pomeps.org/pomeps-studies-39-the-covid-19-pa ndemic-in-the-middle-east-and-north-africa.

Rocha Menocal, Alina. 2014. Getting Real about Politics: From Thinking Politically to Working Differently. London: Overseas Development Institute.

Royaume du Maroc, Ministère de l'Intérieur, Direction Générale des Collectivités Locales. 2016. “Loi Organique Relative aux Regions.” Dahir n¹-15-83 du 20 ramadan 1436 ( 7 juillet 2015) portant promulgation de la loi organique $n^{\circ}$ 111-14 relative aux regions, Bulletin Officiel N ${ }^{\circ} 6440$ du 09 Joumada I 1437 (18 Février 2016), Accessed March 31, 2021. http:/www.pncl.gov.ma/fr/Publication/ regle/Pages/loi-organique-relative-\%C3\%A0-la-r\%C3\%A9gion-.aspx.

Runde, Daniel. 2015. “Ensuring the World Bank's Relevance.” Forbes.com, March 16. Accessed March 31, 2021. https://www.forbes.com/sites/danielrunde/2015/03 /16/ensuring-world-bank-relevance/?sh=d207aa87feb0.

Salman, Lana. 2017. "What we Talk About When we Talk about Decentralization? Insights from Post-revolution Tunisia.” L'Année du Maghreb 16: 91-108.

Schlumberger, Oliver (ed.). 2007. Debating Arab Authoritarianism. Dynamics and Durability in Nondemocratic Regimes. Stanford, CA: Stanford University Press. 
Shalaby, Marwa, and Sylvia I. Bergh. 2020. "Power to the People? The Right to Information Law in Morocco" Sada online journal, September 30. Accessed March 31, 2021. https://carnegieendowment.org/sada/82835.

Tarchouna, Lotfi. 2019. "The Tunisian Experience of Decentralization since 2014." Research Paper, Arab Reform Initiative. Accessed March 31, 2021. https://www. arab-reform.net/wp-content/uploads/pdf/Arab_Reform_Initiative_en_the-tunisia n-experience-of-decentralization-since-2014_5953.pdf?ver=db6fd49d7709e7666e8 b8d5a1b61ab53.

Tunisian Ministry of Local Affairs and the Environment. 2021. "Portail des Collectivités Locales.” Accessed March 31, 2021. http://www.collectiviteslocales. gov.tn.

UMap. 2021. “Initiative pour le Développement Municipal.” Accessed March 31, 2021. http://umap.openstreetmap.fr/de/map/initiative-pour-le-developpement-m unicipal_437273\#5/35.048/12.283.

Van Hüllen, Vera. 2019. "Negotiating Democracy with Authoritarian Regimes EU Democracy Promotion in North Africa." Democratization 26 (5): 869-888. doi: 10.1080/13510347.2019.1593377.

Vollmann, Erik, Miriam Bohn, Rolland Sturm, and Thomas Demmelhuber. 2020. "Decentralisation as Authoritarian Upgrading? Evidence from Jordan and Morocco." The Journal of North African Studies, 1-32. doi: 10.1080/13629387.2020.17 87837.

Vollmann, Erik. 2020. "Comparative Decentralization in the MENA" In The Dynamics of Decentralization in the MENA: Processes, Outcomes, and Obstacles. The Program on Governance and Local Development (GLD) Working Paper No. 31, edited by Marwa Shalaby, Chagai Weiss, Ellen Lust, Kristen Kao, Erik Vollmann, Sylvia I. Bergh, Ezra Karmel, Miriam Bohn, Intissar Kherigi, and Zeynep Kadirbeyoglu, 9-22. Gothenburg: University of Gothenburg.

Volpi, Frédéric. 2017. Revolution and Authoritarianism in North Africa. London: Hurst.

von Soest, Christian. 2015. "Democracy Prevention: The International Collaboration of Authoritarian Regimes.” European Journal of Political Research 54 (4): 623-638. doi: 10.1111/1475-6765.12100.

Whaites, Alan, Eduardo Gonzalez, Sara Fyson, and Graham Teskey, (eds.). 2015. A Governance Practitioner's Notebook: Alternative Ideas and Approaches. Paris: OECD.

World Bank. 2008. Decentralization in Client Countries: An Evaluation of World Bank Support, 1990-2007. Washington DC: World Bank.

World Bank. 2014. "Program Appraisal Document on a Proposed Loan in the Amount of Euro 217 million (US\$300 million equivalent) to the Republic of Tunisia for the Urban Development and Local Governance Program in Tunisia, June 27, 2014. Report No. 88598-TN.” Accessed March 31, 2021. http://docume nts1.worldbank.org/curated/en/994861468117292382/pdf/885980PAD0P130010 Box385274B00OUO090.pdf.

World Bank. 2017. "Bank Policy: Program-for-Results Financing, Catalogue Number OPS5.04-POL.107.” World Bank, November 10. Accessed March 31, 2021. https://ppfdocuments.azureedge.net/f9e36a3b-72e0-4edb-9fdc-96bf555c7208.pdf. 
World Bank. 2019a. "Program Appraisal Document on a Proposed Loan in the Amount of Euro 271.8 million (US\$300 million equivalent) to the Kingdom of Morocco for a Municipal Performance Program-for-Results. Report No. PAD3282." World Bank, October 16. Accessed March 31, 2021. http://document s1.worldbank.org/curated/en/935151573441234720/pdf/Morocco-Municipal-Perf ormance-Program-for-Results-Project.pdf.

World Bank. 2019b. "Program-for-Results: Proposal to Remove the Cap on Commitment Authority. Operations Policy and Country Services.” World Bank, April 4. Accessed March 31, 2021. http://documents1.worldbank.org/curated/en/ $188011557406617235 / \mathrm{pdf} /$ Program-for-Results-Proposal-to-Remove-the-Cap-onCommitment-Authority.pdf.

World Bank. 2020a. "Implementation Status \& Results Report - Municipal Performance Program (P168147) - Sequence No: 02.” World Bank, August 20. Accessed March 31, 2021. http://documents.worldbank.org/curated/en/3123315979 54688974/Disclosable-Version-of-the-ISR-Municipal-Performance-Program-P168 147-Sequence-No-02.

World Bank. 2020b. "Implementation Status \& Results Report - TN-Urban Dev. and Local Governance (P130637) - Sequence No. 12.” World Bank, October 28. Accessed March 31, 2021. http://documents.worldbank.org/curated/en/23973160 3908344673/Disclosable-Version-of-the-ISR-TN-Urban-Dev-and-Local-Governan ce-P130637-Sequence-No-12.

World Bank. 2020c. "Bank Directive: Program-for-Results Financing, Catalogue Number OPS5.04-DIR.107.” World Bank, September 17. Accessed March 31, 2021. https://ppfdocuments.azureedge.net/1b2b69a7-6a9e-43d6-8f3c-eeed174f9c9 b.pdf.

World Bank. 2021. "Implementation Status \& Results Report - Municipal Performance Program (P168147) - Sequence No: 03.” World Bank, March 2. Accessed March 31, 2021. http://documents.worldbank.org/curated/en/456401614694310 637/Disclosable-Version-of-the-ISR-Municipal-Performance-Program-P168147-S equence-No-03.

Yanguas, Pablo, and David Hulme. 2015. "Barriers to Political Analysis in Aid Bureaucracies: From Principle to Practice in DFID and the World Bank.” World Development 74: 209-219. doi: 10.1016/j.worlddev.2015.05.009.

Yerkes, Sarah, and Marwan Muasher. 2018. Decentralization in Tunisia: Empowering Towns, Engaging People. Washington D.C.: Carnegie Endowment for International Peace.

Yousfi, Hèla. 2019. "Reshaping State/Local Communities Relations in Tunisia: The Socio-Cultural and Institutional Challenges of the Decentralization Project.” European Management Journal 37 (5): 625-636. doi: 10.1016/j.emj.2019.05.0 02. 